\title{
The Market for News
}

\section{Citation}

Mullainathan, Sendhil, and Andrei Shleifer. 2005. "The Market for News." American Economic Review 95 (4) (September): 1031-1053. doi:10.1257/0002828054825619.

\section{Published Version}

doi:10.1257/0002828054825619

\section{Permanent link}

http://nrs.harvard.edu/urn-3:HUL.InstRepos:33078973

\section{Terms of Use}

This article was downloaded from Harvard University's DASH repository, and is made available under the terms and conditions applicable to Other Posted Material, as set forth at http:// nrs.harvard.edu/urn-3:HUL.InstRepos:dash.current.terms-of-use\#LAA

\section{Share Your Story}

The Harvard community has made this article openly available.

Please share how this access benefits you. Submit a story.

Accessibility 


\title{
The Market for News
}

\author{
By Sendhil Mullainathan And Andrei Shleifer*
}

\begin{abstract}
We investigate the market for news under two assumptions: that readers hold beliefs which they like to see confirmed, and that newspapers can slant stories toward these beliefs. We show that, on the topics where readers share common beliefs, one should not expect accuracy even from competitive media: competition results in lower prices, but common slanting toward reader biases. On topics where reader beliefs diverge (such as politically divisive issues), however, newspapers segment the market and slant toward extreme positions. Yet in the aggregate, a reader with access to all news sources could get an unbiased perspective. Generally speaking, reader heterogeneity is more important for accuracy in media than competition per se. (JEL D23, L82)
\end{abstract}

Several recent books have accused mainline media outlets of reporting news with a heavy political bias. Bernard Goldberg (2002) and Ann Coulter (2003) argue that the bias is on the left, and provide numerous illustrations of their argument, while Eric Alterman (2003) and Al Franken (2003) argue that the bias is on the right, with equally numerous illustrations. In principle, media bias can come from the supply side, and reflect the preferences of journalists (David Baron, 2004), editors, or owners (Besley and Andrea Prat, 2004; Simeon Djankov et al., 2003). Alternatively, it can come from the demand side, and reflect the news providers' profit-maximizing choice to cater to the preferences of the consumers. We examine, theoretically, the determinants of media accuracy in such a demand-side model, focusing specifically on the effects of reader beliefs, reader heterogeneity, and competition on media bias. We argue that the analysis of media accuracy

\footnotetext{
* Mullainathan: Department of Economics, 208 Littauer Center, Harvard University, Cambridge, MA 02138 (e-mail: mullain@fas.harvard.edu); Shleifer: Department of Economics, M9 Littauer Center, Harvard University, Cambridge, MA 02138 (e-mail: ashleifer@ harvard.edu). We are extremely grateful to Alberto Alesina, Daniel Benjamin, Tim Besley, Filipe Campante, Gene D'Avolio, Glenn Ellison, Josh Fischman, Edward Glaeser, Matthew Gentzkow, Simon Johnson, Emir Kamenica, Lawrence Katz, David Laibson, Dominique Olie Lauga, Emily Oster, Richard Posner, Jesse Shapiro, Jeremy Stein, Lawrence Summers, and three anonymous referees for comments. This paper is a substantially revised version of an earlier paper entitled "Media Bias."
}

relies crucially on how one conceptualizes the demand for news.

In the traditional conception of the demand for news, consumers read, watch, and listen to the news in order to get information. The quality of this information is its accuracy. The more accurate the news, the more valuable is its source to the consumer. Pressure from audiences and rivals forces news outlets to seek and deliver more accurate information, just as market forces motivate auto-makers to produce better cars. ${ }^{1}$

This conception of the news as a source of pure information is dramatically different from that of noneconomists studying the media. According to these scholars, private media want to sell newspapers and television programs, as well as advertising space. To do that, they provide a great deal of pure entertainment. But even with news, audiences want their sources not only to inform but also to explain, interpret, persuade, and entertain. To meet this demand, media outlets do not provide unadulterated information, but rather tell stories that hang together and have a point of view, what is referred to in the business as "the narrative imperative."

\footnotetext{
${ }^{1}$ Ronald Coase (1974), Besley and Robin Burgess (2002), Besley and Prat (2002), Djankov et al. (2003), David Stromberg (2001), and Alexander Dyck and Luigi Zingales (2002) all advance this view of competition in the media as delivering greater accuracy.

${ }^{2}$ H. L. Mencken (1920), Walter Lippmann (1922), Samuel Hayakawa (1940), Michael Jensen (1979), Doris Graber (1984), James Hamilton (2003), and the standard
} 
In this view, news provision can be analyzed in the same way as entertainment broadcasting. ${ }^{3}$

In this paper, we examine these two conceptions of what the consumers want and what the media deliver, and evaluate media accuracy under different scenarios. We show, in particular, that these two conceptions have radically different implications for the accuracy of news in the competitive media, and more specifically on the question of which news issues will be reported more accurately.

Our model of rational readers seeking information shows that, indeed, consistent with economists' priors, media reporting is unbiased. We compare this to a specific behavioral model (of which the rational consumers are a special case), which relies on two assumptions, one about reader preferences and one about the technology of delivering news. ${ }^{4}$ We assume that readers hold biased beliefs, which might come from their general knowledge and education, from previous news, from prejudices and stereotypes, or from the views of politicians or political parties they trust. With respect to preferences, we assume that readers prefer to hear or read news that is more consistent with their beliefs. Such biased readers might believe, for example, that corporate executives are cheats and crooks, and these readers prefer news about their indictments to news about their accomplishments. They might think that China is up to no good with respect to the United States, and appreciate stories about Chinese spies. Some readers might like President Bill Clinton and prefer to read about partisan Republicans persecuting the hard-working president; others might dislike Clinton and look for stories explaining, in salacious detail, the impeachability of his offenses.

The idea that people appreciate, find credible, enjoy, and remember stories consistent with

communications textbook (Werner Severin and James Tankard, Jr., 1992) all advance this view of news.

${ }^{3}$ Entertainment broadcasting is analyzed by Peter Steiner (1952), Michael Spence and Bruce Owen (1977), Ronald Goettler and Ron Shachar (2001), and Esther Gal-Or and Anthony Dukes (2003). Jean Gabszewicz et al. (2001) take the approach closest to ours by conceptualizing news provision in a Hotelling framework. They examine how advertisers have an impact on content, whereas we focus on media accuracy.

${ }^{4}$ For concreteness, we talk about newspapers, although our argument applies equally well to television and radio. their beliefs is standard in the communications literature (Graber, 1984; Severin and Tankard, 1992). Basic research in psychology strongly supports it. Research on memory suggests that people tend to remember information consistent with their beliefs better than information inconsistent with their beliefs (Frederic Bartlett, 1932). Research on information processing shows people find data inconsistent with their beliefs to be less credible and update less as a result (Charles Lord et al., 1979; John Zaller, 1992; Matthew Rabin and Joel Schrag, 1999). According to Graber (1984, p. 130), "stories about economic failures in third world countries were processed more readily than stories about economic successes." People seek information that confirms their beliefs (Josh Klayman, 1995). When people categorize, they tend to ignore category-inconsistent information unless it is large enough to induce category change (Susan Fiske, 1995; Mullainathan, 2002). Severin and Tankard (1992) see the demand for cognitive consistency as crucially shaping which news people listen to, and which they ignore.

Our second assumption is that newspapers can slant the presentation of the news to cater to the preferences of their audiences. The term "slanting" was introduced by Hayakawa (1940), and defined as "the process of selecting details that are favorable or unfavorable to the subject being described." Slanting is easily illustrated in a simple example. Suppose that the Bureau of Labor Statistics (BLS) releases data that show the rate of unemployment rising from 6.1 percent to 6.3 percent. What are the different ways a paper can report this number? One is a single sentence report that simply presents the above fact. But there are alternatives. Consider just two.

(a) Headline: Recession Fears Grow. New data suggest the economy is slipping into a recession. The BLS reports that the number of unemployed grew by 200,000 in the last quarter, reaching 6.3 percent. John Kenneth Galbraith, the distinguished Harvard economist, sees this as an ominous sign of the failure of the administration's policies. "Not since Herbert Hoover has a president ignored economic realities so blatantly. This news is only the beginning of more to come," he said. (Accompanying picture: a 
long line for unemployment benefits in Detroit, Michigan.)

(b) Headline: Turnaround in Sight. Is the economy poised for an imminent turnaround? Data from the BLS suggest that it might be. Newly released figures show unemployment inching up just 0.2 percent last quarter. Abbie Joseph Cohen, the chief stock market strategist at Goldman Sachs, sees the news as highly encouraging. "This is a good time to increase exposure to stocks," she says, "both because of the strong underlying fundamentals and because the softness in the labor market bodes well for corporate profitability." (Accompanying picture: smiling Abbie Joseph Cohen.)

Each of these stories could easily have been written by a major U.S. newspaper. In fact, stories like these, in light of public disclosure of identical facts, are written every day. Neither story says anything false, yet they give radically different impressions. Each cites an authority, without acknowledging that a comparably respectable authority might have exactly the opposite interpretation of the news. Each omits some aspect of the data: the first by neglecting to mention the starting point of the unemployment rate, the second by ignoring unemployment levels. Each uses a headline, and a picture, to persuade readers who do not focus on the details. Each, in other words, slants the news by not telling the whole truth, but the articles are slanted in opposite directions. ${ }^{5}$

Our model of the market for news combines the assumption of readers preferring stories consistent with their beliefs with the assumption that newspapers can slant stories toward specific beliefs. We examine two crucial aspects of this environment. First, we consider two alternative assumptions about the nature of competition: monopoly versus duopoly. Our model of media competition is analogous to a Hotelling model of product placement (Jean Tirole, 1988, ch. 7). Newspapers locate themselves in the product space through their reporting strategies (i.e., how they slant). Readers' beliefs determine their "transportation" costs, since they face psy-

\footnotetext{
${ }^{5}$ Persuasion can also work through outright fabrication of news, as was done routinely by the Communist press, and occasionally even in Western newspapers (e.g., Jason Blair's reporting for the New York Times.)
}

chic costs of reading papers whose reporting does not cater to their beliefs. We ask whether competition by itself eliminates or reduces the slanting of news, as economists often argue. We show that the answer for biased readers is clearly no. Competition generally reduces newspaper prices, but does not reduce, and might even exaggerate, media bias.

Second, we study heterogeneity of reader beliefs. What effect does such heterogeneity have on the nature of slanting and the overall accuracy in media? What is the impact of competition on media accuracy when reader beliefs are heterogeneous, as in the case of beliefs about President Clinton? To answer this question, it is crucial to distinguish between an average reader, who reads one source of news, and a hypothetical conscientious reader, who reads multiple sources. In general, competition with heterogeneous readers increases the slanting by individual media sources. But with heterogeneous readers, the biases of individual media sources tend to offset each other, so the beliefs of the conscientious reader become more accurate than they are with homogeneous readers. Our central finding is that reader heterogeneity plays a more important role for accuracy in media than does competition.

At a broader level, this paper contributes to one of the central issues in economics, namely whether the presence of rational, profit-maximizing firms eliminates any effect of irrational participants on market "efficiency." In the context of financial markets, Milton Friedman (1953) argued long ago that it does, and that rational arbitrageurs keep financial markets efficient. Subsequent research, however, has proved him wrong, both theoretically and empirically (Shleifer, 2000; Markus Brunnermeier and Stefan Nagel, 2004). One finding of this research is that, in some situations, such as stock market bubbles, it might pay profit-maximizing firms to pump up the tulips rather than eliminate irrationality (Brad DeLong et al., 1990). Subsequent research has considered the interaction between biased individuals and rational entrepreneurs in other contexts, such as the incitement of hatred (Glaeser, 2005), political competition (Kevin Murphy and Shleifer, 2004), and product design (Xavier Gabaix and Laibson, 2004). Here we ask a closely related question for the market for news: does competition among profit-maximizing news providers 
eliminate media bias? We find that the answer, in both financial and political markets, is no. Powerful forces motivate news providers to slant and increase bias rather than clear up confusion. The crucial determinant of accuracy is not competition, per se, but consumer heterogeneity.

\section{Model Setup}

Readers are interested in some underlying variable $t$, such as the state of the economy, which is distributed $N\left(0, v_{\mathrm{t}}\right)$. Let $p=1 / v_{t}$ denote the precision. Readers hold a belief about $t$ that may be biased; beliefs are distributed $N\left(b, v_{t}\right)$. Thus, readers are potentially biased about the expected value of $t$, but have the correct variance.

Newspapers are in the business of reporting news about $t$. They receive some data $d=t+$ $\varepsilon$, where $\varepsilon \sim N\left(0, v_{\varepsilon}\right)$. In the example from the introduction, these data might be an unemployment rate release. We assume that the papers then report the data with a slant $s$, so the reported news is $n=d+s$. For most of the paper, the exact technology of slanting is not important, but in Section V we study a specific one.

\section{A. Reader Utility}

Suppose readers are rational and unbiased. All they want is information. They dislike slanting because it is costly both in effort and the time it takes to read slanted news and figure out the "truth." In the BLS example, the report of the first newspaper does not tell the reader how much the unemployment rate changed, while that of the second newspaper does not contain the unemployment rate. To get a full picture, the reader needs more information. We assume that a rational reader's utility is decreasing in the amount of slanting. So, if he reads a newspaper, his utility is:

$$
U_{r}=\bar{u}-\chi s^{2}-P
$$

where $P$ is the paper's price. If he does not read the newspaper, he receives utility 0 .

Biased readers, on the other hand, get disutility from reading news inconsistent with their beliefs. We model consistency as the distance between the news and the reader's beliefs, $b$, measured as $(n-b)^{2}$. In the BLS example, a reader optimistic about the economy experiences disutility when reading stories that suggest a recession. At the same time, even biased readers dislike blatant and extreme slanting, at least in the long run. Holding constant the consistency with beliefs, they prefer less slanted news. ${ }^{6}$ So, if he reads the newspaper, the overall utility of a biased reader is:

$$
U_{b}=\bar{u}-\chi s^{2}-\phi(n-b)^{2}-P
$$

where $\phi>0$ calibrates his preference for hearing confirming news.

\section{B. Newspaper Strategy}

Before seeing the data $d$, a newspaper announces its slanting strategy $s(d)$ and the price $P$ it charges. Potential readers buy the paper if the price $P$ is lower than the expected utility associated with reading the paper, $E_{d}[U(s(d))]$. To form expected utility, expectations are taken over $d$ and are assumed to be the true expectations $\left(d \sim N\left(t, v_{d}\right)\right)$ rather than the biased ones. This approach crudely captures the idea that this is a long-run game. Readers get a general sense of how much pleasure the paper provides them and make their purchasing decisions accordingly. It then makes more sense to think of expected utility using the empirical distributions. Practically, in the model both assumptions about expectations produce the same results.

Once readers decide whether to buy the paper, the paper observes its signal $d$ and reports $n=d+s(d)$. Readers read the news and receive their utility. Timing of the full game is as follows:

(a) The newspaper announces a strategy $s(d)$ for how to report the news. When there are two papers, both announce strategies simultaneously.

(b) Price $P$ is announced. When there are two papers, both announce prices simultaneously, after the other paper has revealed its strategy.

\footnotetext{
${ }^{6}$ This assumption is immaterial to our results. All we require is that newspapers face some quadratic cost of slanting. This cost could just as easily arise on the supply side, with firms facing a technological or private reputational cost of slanting, and the results would be the same. The necessary feature is that firms cannot slant freely.
} 
(c) Individuals decide whether to buy the paper based on average utility associated with its strategy $s(d)$ and price $P$.

(d) Newspaper receives data $d$ and reports news $d+s(d)$. If there are two papers, they receive the same data $d$ and report $d+s_{j}(d)$ where $j=1,2$.

(e) If individuals buy the paper, they read the news and receive utility.

\section{Cases Considered}

We consider two different distributions of reader beliefs: homogeneous and heterogeneous. Homogeneity means that all readers hold the same beliefs $b$ with precision $p$. For example, all or nearly all readers in the United States might believe that the Russians are corrupt or that the French are anti-American. Heterogeneity means that there is a distribution of reader beliefs. Such heterogeneity could come from political ideology. For example, opinions about U.S. presidents often divide along party lines. We assume that heterogeneous beliefs are distributed uniformly between $b_{1}$ and $b_{2}$ where $b_{1}<b_{2}$ and $b_{2}>0$. Readers in this uniform distribution are indexed by $i \in[1,2]$ so that reader $i$ holds belief $b_{i}$. All readers hold their beliefs with precision $p$. We denote by $\bar{b}$ the average of $b_{1}$ and $b_{2}$. We also denote reader $i$ 's utility function as $u_{i}(d)$ or $u_{b_{i}}(d)$, depending on context. The homogeneous and heterogeneous cases are designed to capture two different types of issues: ones on which there is consensus in the population and ones where there is substantial disagreement.

We also examine two cases of industry structure. In the first case, there is a single monopolistic newspaper. In the second, there are two newspapers, indexed by $j=1,2$, each seeing the same data $d$. For a monopolist, $s_{\text {hom }}^{*}$ and $s_{\text {het }}^{*}$ denote the optimal slanting strategy for the homogeneous and heterogeneous case. Similarly, $P_{\text {hom }}^{*}$ and $P_{\text {het }}^{*}$ denote optimal price in these cases. For duopolists, $s_{j \text {,hom }}^{*}$ and $s_{j, \text { het }}^{*}$ denote the optimal strategy of paper $j=1,2$ in the homogeneous and heterogeneous cases, respectively. Similarly, $P_{j, \text { hom }}^{*}$ and $P_{j, \text { het }}^{*}$ denote each duopolist's optimal price in these two cases.

This formalism of industry structure is similar in spirit to a Hotelling model. Readers' beliefs resemble consumers' preferred locations. Their dislike of inconsistent news resembles transportation costs. Firms' choice of a slanting rule resembles their choice of location. In this context, our utility function implies quadratic transportation costs and our distribution of reader beliefs in the heterogeneous case corresponds to a uniform distribution of consumers. Consequently, many of our proofs resemble the proofs for the Hotelling models in this case (Claude d'Aspremont et al., 1979). ${ }^{7}$

\section{Defining Bias}

We are interested in the extent of newspaper bias in the market. We measure this by the average bias of the newspapers in the market, weighted by their market share. In the homogeneous case, where there is only one kind of reader, we simply define bias as

$$
\mathrm{ARB}_{\text {hom }}=E_{d}\left[(n-d)^{2}\right]
$$

where $n$ is the news read by these readers. So bias is defined as the average amount by which the news read deviates from the data for the average reader.

In the heterogeneous case, let $n_{i}$ be the news read by reader $i \in[1,2]$. Bias is then defined as:

$$
\mathrm{ARB}_{\text {het }}=\int_{i} E_{d}\left[\left(n_{i}-d\right)^{2}\right] .
$$

This measures the average bias that readers encounter.

\section{Rational Readers}

When readers are rational, newspapers face only a disincentive to slant. The following proposition summarizes the outcomes for different cases.

PROPOSITION 1: Suppose readers are rational. Then, whether readers are homogeneous or

\footnotetext{
${ }^{7}$ As with all Hotelling models, the assumptions on transportation costs matter. With linear transportation costs, an equilibrium does not exist. But while the results depend on nonlinear transportation costs, they are not specific to the quadratic. Other convex functions produce similar results (Nicholas Economides, 1986). See Steffen Brenner (2001) for a survey. Similarly, as with all Hotelling models, the assumption of Bertrand competition is key to our results.
} 
heterogeneous, the monopolist does not slant and charges the same price:

$$
s_{\text {hom }}^{*}=s_{\text {het }}^{*}=0
$$

and

$$
P_{\text {hom }}^{*}=P_{\text {het }}^{*}=\bar{u} \text {. }
$$

In the duopolist case as well, papers do not slant and once again charge the same price:

$$
s_{j, \text { hom }}^{*}=s_{\text {j.het }}^{*}=0
$$

and

$$
P_{j, \text { hom }}^{*}=P_{\text {j.het }}^{*}=0
$$

for all $j$ on the equilibrium path. The only effect of competition is to lower prices.

\section{PROOF:}

See Appendix for all proofs.

Proposition 1 illustrates the normal logic of economists' thinking about the media. When readers seek accuracy in news, newspapers pass on, without slant, the information they receive. Since perfect quality is achieved even without competition, the effect of competition is to reduce the price that readers pay. With both monopoly and duopoly, consumers get what they want and there is no media bias. ${ }^{8}$ In the rest of the paper, we focus on the case of biased readers.

\section{Homogeneous Biased Readers}

The following proposition summarizes the monopolist's behavior with homogeneous readers.

PROPOSITION 2: A monopolist facing a homogeneous audience chooses:

$$
s_{\text {hom }}^{*}(d)=\frac{\phi}{\chi+\phi}(b-d)
$$

\footnotetext{
${ }^{8}$ As is clear from the proof of the proposition, this result generalizes trivially to $J>2$ newspapers.
}

$$
P_{\text {hom }}^{*}=\bar{u}-\frac{\chi \phi}{\chi+\phi}\left[b^{2}+v_{d}\right]
$$

if $\bar{u}>[\chi \phi /(\chi+\phi)]\left[b^{2}+v_{d}\right]$. If not, there exists no slanting strategy that results in the news being read.

Because the monopolist can capture all surplus through the price he charges, to maximize profits he merely maximizes expected utility. The news he reports is:

$$
n=\frac{\phi}{\chi+\phi} b+\frac{\chi}{\chi+\phi} d .
$$

The reported news is a convex combination of bias and data, with weights given by utility parameters. In this case, we say the monopolist "slants toward $b$." Since this linear slanting strategy will reappear throughout the paper, we define:

$$
s_{B}(d) \equiv \frac{\phi}{\chi+\phi}(B-d) .
$$

With this notation, the proposition above can be rewritten as $s_{\mathrm{hom}}^{*}(d)=s_{b}(d)$. The monopolist chooses this linear form because expected utility functions are separable in the value of $d$. The monopolist maximizes utility for every given value of $d$, which leads him to slant toward a biased reader's beliefs. ${ }^{9}$

The following corollary derives comparative statics for the magnitude of slanting.

COROLLARY 1: In the homogeneous reader case, slanting increases with the reader preference for hearing confirmatory news and declines with the cost of slanting:

$$
\begin{gathered}
\frac{\partial\left|s_{\text {hom }}^{*}(d)\right|}{\partial \phi}>0 \\
\frac{\partial\left|s_{\text {hom }}^{*}(d)\right|}{\partial \chi}<0 .
\end{gathered}
$$

\footnotetext{
${ }^{9}$ Even when $b=0$, there is slanting. This is because even a reader who has zero bias ex ante does not want to change his mind ex post. Consequently, the monopolist slants news toward the reader's bias, 0 .
} 
Proposition 2 suggests a theory of spin. Suppose that a politician, or some other figure of authority, has a first mover advantage, i.e., can choose which data $d$ gets presented to the media first. The papers slant the data toward reader beliefs, but by Proposition 2, $d$ will have significant influence on what papers report as compared to their getting data from an unbiased source. For example, by preemptively disclosing that a Chinese spy has been found in Los Alamos, a politician can focus the discussion on the risk to U.S. security from Chinese espionage, rather than on the administrative incompetence in the Department of Energy. This effect becomes even more powerful in a more general model of sequential reporting. In this case, the initial spin may shape reader priors, which future papers face and consequently slant news toward. The initial spin would then be reinforced even by ideologically neutral papers.

The condition $\bar{u}>[\chi \phi /(\chi+\phi)]\left[b^{2}+v_{d}\right]$ guarantees that this reader's reservation utility $\bar{u}$ is high enough that he prefers reading the optimally biased news to no news. From now on, we assume that this condition holds.

ASSUMPTION 1: Reader utility from news is high enough that readers prefer the equilibrium news to no news:

$$
\bar{u}>\frac{\chi \phi}{\chi+\phi}\left[b^{2}+v_{d}\right] .
$$

With this assumption in place, we now turn to competition. How does competition between two newspapers affect the results above?

PROPOSITION 3: Suppose duopolists face a homogeneous audience. Then there is an equilibrium in which duopolists choose on the equilibrium path:

$$
s_{j, \mathrm{hom}}^{*}(d)=\frac{\phi}{\chi+\phi}(b-d)
$$

and prices

$$
P_{j, \text { hom }}^{*}=0
$$

for both $j=1,2$. Readers are indifferent between the two papers.
With a homogeneous audience, competition is Bertrand-like: it simply drives prices down to zero. ${ }^{10}$ Each duopolist's slant is exactly equal to the monopolist's slant, and they split the readers between them. The following corollary summarizes the impact of competition on bias in the homogeneous case. ${ }^{11}$

COROLLARY 2: For a homogeneous audience, both monopoly and duopoly produce the same amount of average reader bias:

$$
\operatorname{ARB}_{\text {mon }}\left(v_{d}\right)=\operatorname{ARB}_{\text {duo }}\left(v_{d}\right) .
$$

Propositions 2 and 3 are the first critical results of the paper. They show that when readers have homogeneous biases, competition does not eliminate them-it only leads to price reductions. Both monopolists and duopolists cater to reader prejudices. These propositions basically say that one cannot expect accuracy-even in the competitive media- on issues where the readers share beliefs. One example of such uniformity might be foreign affairs, where there may be a great deal of commonality of views toward a particular foreign country, such as Russia, China, or France. Another example is law enforcement, where most readers might sympathize with efforts by the government to prosecute members of a disliked group (e.g., the Arabs or the rich).

\section{Heterogeneous Biased Readers}

What happens when readers differ in their beliefs? Newspapers must now decide which one of the heterogeneous reader groups is its target audience.

PROPOSITION 4: Suppose a monopolist faces a heterogeneous audience with $\bar{b}=0$. There exists a $C_{m}$, which depends on the parameters of the model, that determines the monopolist's strategy. If $b_{2}-b_{1}<C_{m}$, the monopolist maximizes profits by choosing:

\footnotetext{
${ }^{10}$ For this same reason, and as is clear from the proof of the proposition, this result holds for any number of newspapers $J \geq 2$.

${ }^{11}$ The stated equilibrium for the duopolists is not unique because any strategy profile that differs on a set of measure zero would also be an equilibrium.
} 
(19) $s_{\text {het }}^{*}=s_{\bar{b}}(d)=\frac{\phi}{\chi+\phi}(\bar{b}-d)=-\frac{\phi}{\chi+\phi} d$

$$
P_{\text {het }}^{*}=\bar{u}-\frac{\phi \chi}{\chi+\phi} v_{d}-\phi^{2} b_{2}^{2} \text {. }
$$

If $b_{2}-b_{1}>C_{m}$ the monopolist chooses not to cover the market, i.e., not all readers read the paper.

According to Proposition 4, the monopolist covers the market if the dispersion of reader beliefs is small enough. If beliefs are too far apart, readers on either extreme will not read the paper. $^{12}$

Duopolists, in contrast, respond completely differently to heterogeneity. For tractability, we now consider only the situation where duopolists choose linear strategies.

PROPOSITION 5: Suppose duopolists choose linear strategies of the form $s_{B}(d)=[\phi /(\chi+$ $\phi)](B-d)$ and that $\bar{b}=0$. Then there exists $a$ constant

$$
C_{d}=\sqrt{\frac{4}{33}\left[\frac{\phi+\chi}{\phi^{2}} \bar{u}-\frac{\chi}{\phi} v_{d}\right]}
$$

such that if $b_{2}<C_{d}$ duopolists choose:

$$
\begin{aligned}
s_{1, \text { het }}^{*}(d) & =\frac{\phi}{\chi+\phi}\left(\frac{3}{2} b_{1}-d_{1}\right) \\
s_{2, \text { het }}^{*}(d) & =\frac{\phi}{\chi+\phi}\left(\frac{3}{2} b_{2}-d_{2}\right) \\
P_{j, \text { het }}^{*} & =\frac{6 \phi^{2}}{\chi+\phi} b_{2}^{2}
\end{aligned}
$$

where we assume, without loss of generality,

\footnotetext{
${ }^{12}$ If $\bar{b}=0$, but $b_{2}-b_{1}>C_{m}$, the monopolist would use the same slanting strategy as in Proposition 4, but would charge a high enough price that not all people read the paper. The case where $\bar{b} \neq 0$ is more complicated. The monopolist would not slant toward $\bar{b}$ anymore. Instead, he would slant toward a point between $\bar{b}$ and 0 . This is because readers closer to the origin enjoy higher overall surplus from reading the paper (see Lemma (A1)). Consequently, the monopolist would prefer a distribution of readers closer to the origin so as to be able to charge higher prices.
}

that firm 1 slants toward the left and firm 2 slants toward the right. All readers read the newspaper.

Each duopolist positions himself as far away from the other as possible. The reported news in this case equals

(25) $n_{j}=d+s_{j, \mathrm{het}}^{*}(d)=\frac{\phi}{\chi+\phi} \frac{3}{2} b_{j}+\frac{\chi}{\chi+\phi} d_{j}$.

The reported news is a weighted average of the actual data $d$ and $3 / 2 b_{j}$, where $b_{j}$ is the endpoint of the reader bias distribution. So duopolists are slanting news toward $3 / 2 b_{j}$, points that are more extreme than the most extreme readers in the population.

This is analogous to the standard Hotelling result with uniform distributions and quadratic transportation costs (Tirole, 1988; d'Aspremont et al., 1979). As in the standard Hotelling model, the monopolist caters to both audiences unless they are too far apart, while duopolists maximally differentiate. But in the standard Hotelling model, firms are constrained to choose within the preference distribution. In our model, they can choose positions outside the distribution of reader bias, and in equilibrium choose very extreme positions. ${ }^{13}$

To see why this occurs, consider a simple case where $\phi=1, \chi=1, b_{2}=1$ and $b_{1}=-1$. With these parameters, suppose the firms locate at $z_{1} \leq z_{2} \cdot{ }^{14}$ Equilibrium prices then equal (see the proof of Proposition 5):

$$
\begin{aligned}
& P_{1}^{*}\left(z_{1}, z_{2}\right)=\Delta z\left(1+\frac{\bar{z}}{3}\right) \\
& P_{2}^{*}\left(z_{1}, z_{2}\right)=\Delta z\left(1-\frac{\bar{z}}{3}\right)
\end{aligned}
$$

where $\Delta z=z_{2}-z_{1}$ and $\bar{z}=\left(z_{1}+z_{2}\right) / 2$. The more differentiated the duopolists (the greater is

\footnotetext{
${ }^{13}$ If $\bar{b}=0$ but $b_{2}>C_{d}$, the duopolists differentiate less than stated in Proposition 5. The participation constraint of the reader with bias 0 begins to bind and the duopolists locate closer together than in the proposition. If $b_{2}$ is sufficiently large, the duopolists would even end up inside the distribution of reader beliefs so that $\left|z_{j}\right|<\left|b_{j}\right|$.

${ }^{14}$ Recall that "located at $z$ " means the paper biases according to the rule $s_{z}(d)=[\phi /(\chi+\phi)](z-d)$.
} 
$\Delta z$ ), the higher the prices they can charge. Differentiation softens price competition because the temptation to undercut each other diminishes as the firms move farther away from the marginal consumer (who is located between them).

Now consider firm 1's choice of where to locate. When biasing toward $z_{1}$, firm 1 captures all readers between -1 and $x^{*}\left(z_{1}, z_{2}\right)=\bar{z} / 3$. Hence its profits equal $P_{1}^{*}(1+\bar{z} / 3)$. Differentiating with respect to $z_{1}$ gives the first-order condition

$$
\begin{aligned}
& \frac{\partial P_{1}^{*}}{\partial z_{1}}\left(x^{*}\left(z_{1}, z_{2}\right)\right)+P_{1}^{*}\left(\frac{\partial x^{*}}{\partial z_{1}}\right)=0 \\
& \frac{\partial P_{1}^{*}}{z_{1}}\left(1+\frac{\bar{z}}{3}\right)+P_{1}^{*}\left(\frac{1}{3}\right)=0 .
\end{aligned}
$$

Increasing $z_{1}$ (that is, moving closer to the origin) has two effects on profits. The first is a price effect; there is a change in profits because changing position affects the equilibrium prices. The second is a market share effect; there is a change in profits because moving closer to the origin raises market share.

Papers slant toward positions well beyond the extreme consumers because the price effect dominates the market share effect until firms are very far apart. Focusing on the symmetric case with $\bar{z}=0$, the price effect is $\partial P_{1}^{*} / \partial z_{1}=\Delta z / 6-$ 1. The price effect is negative as long as $\Delta z<$ 6 , in other words, until the difference in firm locations is three times as high as the difference in most extreme readers $\left(3\left(b_{2}-b_{1}\right)=6\right)$. The market share effect, on the other hand, is $P_{1}^{*} / 3=$ $\Delta z / 6$. These two effects offset each other to produce an optimum when $\Delta z / 6-1+\Delta z / 6=$ 0 or $\Delta z=3$. At the symmetric equilibrium, the optimum is reached at $\Delta z=-2 z_{1}=3$ or $z_{1}=$ $-3 / 2$. The distance between the newspapers $\left(z_{2}-z_{1}=3\right)$ is greater than the distance between the most extreme readers $\left(b_{2}-b_{1}=2\right)$.

In short, when choosing how to slant, duopolists maximally differentiate themselves. ${ }^{15}$ Practically, this means that news

\footnotetext{
${ }^{15}$ This analysis also illustrates why Proposition 5 is about competition, per se, and not about variety alone. A monopolist who could start two newspapers does not need to differentiate to increase market power. He would differentiate simply to cater to reader tastes, but would not go beyond the most extreme readers as duopolists would.
}

sources can be even more extreme than their most biased readers. One cannot, therefore, infer reader beliefs directly from media bias.

Another point is worth noting:

$$
E\left[\left|\left(s_{j, \text { het }}^{*}(d)\right)\right|\right] \geq E\left[\left|\left(s_{\text {het }}^{*}(d)\right)\right|\right] .
$$

Duopolists always slant more than the monopolist when readers are heterogeneous. In this sense, competition tends to polarize the news. The following corollary summarizes the impact of competition on bias.

COROLLARY 3: Suppose $b_{1}-b_{2}<C_{m}$. In the heterogeneous reader case, competition increases the bias of the average reader:

$$
\operatorname{ARB}_{\text {mon,het }}\left(v_{d}\right)<\operatorname{ARB}_{\text {duo,het }}\left(v_{d}\right) .
$$

Corollary 3 shows that, with heterogeneous readers, competition by itself polarizes readership and, if anything, raises the average reader bias. Entry of a left-wing newspaper or a TV station into a local market previously dominated by a moderate or slightly right-wing monopolist might cause this monopolist to shift his reporting to the right.

Corollary 3 might shed light on the growing controversy in the United States about media bias. Several recent books have angrily attacked media outlets for having a left-wing bias (e.g., Goldberg, 2002; Coulter, 2003). Several equally angry books have responded that other media outlets have an even stronger right-wing bias (Alterman, 2003; Franken, 2003). We suspect that there is a grain of truth in all these books, and that the growing partisanship of alternative media sources is a response to the growth in competition, and market segmentation, in the media. Changes in media technology have led to significant entry, especially in television. If these media sources divide the market along ideological lines, we expect them to become more biased than they were in the regime of moderate competition. This is perhaps what the various commentators are recognizing.

Corollary 3 may also have implications for the effects of entry of new media outlets on the nature of reporting. In a provocative recent study, Gentzkow and Shapiro (2004) examine the responses to a Gallup poll by residents of nine Muslim countries about such topics as the 
United States, terrorism, responsibility for 9/11, and so on. The authors document a striking pattern of factually inaccurate beliefs, but also suggest that the media have a strong effect on these beliefs. In particular, those who watch al-Jazeera (Arab television) are much more likely to hold factually false beliefs (as well as anti-American ones) than those watching CNN. ${ }^{16}$ In concluding their paper, Gentzkow and Shapiro appear to endorse recent proposals favoring an expansion of Western news in the Arab world, because such news is likely to moderate opinions and beliefs.

Our model suggests that caution is appropriate. The people who watch or listen to Western news are already sympathetic to its perspective and might already watch $\mathrm{CNN}$, so they are unlikely to be strongly affected. Additional entry might cause al-Jazeera and similar networks to further differentiate their product by advancing yet more extreme views. The effect might be to radicalize, rather than moderate, their audience.

\section{Reader Heterogeneity and Accuracy in Media}

Our results so far focus on how an average reader in the population is affected. We can also look at the impact of reporting on a conscientious reader, a hypothetical reader who reads all the news available but is too small to affect what is reported. The interesting insights arise in the duopoly case where the hypothetical conscientious reader reads both papers. Since both papers are reporting on the same event, the conscientious reader might in principle be able to use the two to undo the slanting. To understand this process we need a precise model of slanting.

\footnotetext{
${ }^{16}$ These results are not unique to the Muslim world. Steven Kull et al. (2003) document significant confusion among large percentages of U.S. respondents on such questions as Saddam Hussein's culpability in 9/11 and the discovery of weapons of mass destruction in Iraq. The study also finds that those who get their news from Fox News are less well informed about these issues than those who get their news from PBS and NPR.
}

\section{A. Technology of Slanting}

Following Hayakawa (1940), we assume that newspapers slant by selectively omitting specific bits of news, i.e., not reporting the whole truth. ${ }^{17}$ To formalize this idea, suppose that, rather than simply receiving a composite $d=$ $t+\varepsilon$, the newspaper receives a sequence of positive and negative "bits" or facts. In the example from the introduction, these facts could be the unemployment rate, the unemployment rate in the past, expert opinions, other relevant economic indicators, and so on. These bits or facts are modeled as a length $L$ string $f$ consisting of positive $(+1)$, negative $(-1)$, or nonexistent $(\varnothing)$ pieces of news. At each position, the probability of each of these values is a function of $d$, so now instead of simply seeing the composite $d$, the paper sees all the bits of facts that constitute it. The probability that the piece of news in position $i$, denoted $f_{i}$, is positive, negative, or nonexistent is given by the distribution function:

$$
\operatorname{Pr}\left(f_{i}\right)=\left\{\begin{aligned}
+1 & =q g(d) \\
-1 & =q(1-g(d)) \\
\varnothing & =(1-q)
\end{aligned}\right.
$$

where $g(\cdot)$ is a continuous and increasing function that is bounded between 0 and 1 , and $0<$ $q \leq 1$. With probability $1-q$, there is no news at position $i$. If there is news, it is positive with probability $g(d)$ and negative otherwise. Conditional on $d$, these probabilities are iid across different bits on a string. With multiple papers, we assume that they all see the same string $f$.

A newspaper that does not slant at all would simply report the string $f$ without alteration. A reader who sees the string $f$ can draw inferences from the number of +1 's and -1 's, which we define as $N_{+}(f)$ and $N_{-}(f)$, respectively. By the Law of Large Numbers:

$$
\frac{N_{+}(f)}{N_{-}(f)+N_{+}(f)}=g(d)+\eta \rightarrow g(d)
$$

where $\eta$ is a noise term that converges to zero as the length of the string $L \rightarrow \infty$. Consequently, for large $L$, the information the reader receives

\footnotetext{
${ }^{17}$ Importantly, newspapers do not slant by simply manufacturing evidence.
} 
is well approximated by the case in which he simply observes $d$ since $g^{-1}\left[N_{+}(f) /\left(N_{-}(f)+\right.\right.$ $\left.\left.N_{+}(f)\right)\right] \rightarrow d$.

In this formalism, a newspaper slants the signal by selectively omitting positive or negative bits of information. To slant upward, for example, a newspaper drops negative bits. Instead of reporting $+1,-1,-1, \varnothing,+1,-1, \ldots$ it reports $+1, \varnothing, \varnothing, \varnothing,+1,-1 \ldots$, for example. A paper that wishes to slant upward by $s>0$ produces a string $f^{\prime}$ by dropping enough negative bits to guarantee

$$
g^{-1}\left(\frac{N_{+}\left(f^{\prime}\right)}{N_{-}\left(f^{\prime}\right)+N_{+}\left(f^{\prime}\right)}\right) \approx d+s .
$$

Likewise, a paper that wishes to slant negatively by $s<0$ simply drops enough positive bits. As $L \rightarrow \infty$, the paper can choose to drop bits to approximate better and better any given slant $s$.

For simplicity, assume that newspapers omit facts in fixed ways. To slant positively, a paper omits the lowest indexed negative bits until it approximates the desired fraction. To slant negatively, a paper omits the lowest indexed positive bits until it reaches the desired fraction. This assumption is simply one way of formalizing the idea that two papers wishing to slant in a particular direction do so similarly.

\section{B. Cross-Checking}

By cross-checking the facts in the two newspapers, a conscientious reader may be able to reduce the effect of slanting. Suppose each paper receives string $f$, which can be thought of as implying data $d=t+\varepsilon$, and paper $j$ reports string $f_{j}$. There are now several cases. If the implied slants for both papers are positive and $s_{1}>s_{2}>0$, then every fact that paper 1 reports, paper 2 also reports. Moreover, because paper 2 is slanting less, it reports some facts that paper 1 does not. Consequently, a conscientious reader would interpret the news as if she had read only paper 2 . The case where $0>s_{2}>s_{1}$ is similar. On the other hand, if the two papers are on opposite sides of the issue so that $s_{1}>$ $0>s_{2}$, paper 1 omits some negative details to slant upward and paper 2 omits some positive details to slant downward. The conscientious reader, however, can cross-check both papers. Paper 1 reports the positive facts, which paper 2 omits, and paper 2 reports the negative facts, which paper 1 omits. By cross-checking, the conscientious reader gets all the facts, as if she were able to read an unslanted newspaper. Define $\mathrm{xc}(\cdot)$ to be the cross-checking function:

(35) $\operatorname{xc}\left(s_{1}, s_{2}\right)= \begin{cases}\min \left\{s_{1}, s_{2}\right\} & \text { if } s_{1}>0, s_{2}>0 \\ \max \left\{s_{1}, s_{2}\right\} & \text { if } s_{1}<0, s_{2}<0 \\ 0 & \text { otherwise. }\end{cases}$

This function summarizes how the conscientious reader can cross-check the two papers. ${ }^{18}$

Define $n_{c}$ to be the news the conscientious reader is effectively exposed to:

$$
n_{c}= \begin{cases}n & \text { if one newspaper } \\ d+\mathrm{xc}\left(s_{1}, s_{2}\right) & \text { if two newspapers. }\end{cases}
$$

We then define conscientious reader bias analogously to the average reader bias:

$$
\mathrm{CRB}=E_{d}\left[\left(n_{c}-d\right)^{2}\right] .
$$

This definition of conscientious reader bias is independent of heterogeneity of reader beliefs. However, CRB does depend on the equilibrium news reporting, which in turn may depend on the heterogeneity of reader beliefs.

As the discussion on cross-checking suggests, reader heterogeneity can help the conscientious reader quite a bit. To formalize this, let us compare the case of homogeneous readers with bias $b$ to the case of heterogeneous readers with beliefs distributed uniformly on $[b-\delta$, $b+\delta$ ]. The following corollary summarizes our principal finding:

COROLLARY 4: The interaction of reader heterogeneity and duopoly lowers conscientious reader bias. When readers are heterogeneous, conscientious reader bias is lower under duopoly than monopoly:

$$
\mathrm{CRB}_{\text {het,duo }}<\mathrm{CRB}_{\text {het,mon }} \text {. }
$$

\footnotetext{
${ }^{18}$ The extreme cross-checking depends on the two papers slanting stories using the same rule. It is necessary for our results only that the papers use similar rules. Suppose that when one paper omits a fact, it appears in a oppositely slanted paper only with probability $z$. In this case, the cross-checking function becomes $(1-z) s_{1}+(1-z) s_{2}+$ $z \operatorname{xc}\left(s_{1}, s_{2}\right)$. Thus, the qualitative statements we make are preserved.
} 
Under duopoly, conscientious reader bias is lower under heterogeneity than homogeneity:

$$
\mathrm{CRB}_{\text {het,duo }}<\mathrm{CRB}_{\text {hom,duo }} \text {. }
$$

Corollary 4 is the final result of our paper and its bottom line. It points to the absolutely central role that heterogeneity of reader beliefs plays in assuring accuracy in media. We have shown that when readers are homogeneous, competition results in lower prices, but not in accurate news reporting. When readers are heterogeneous, the news received by the average reader might become even more biased as competitive media outlets segment the market. Such market segmentation, however, benefits a conscientious reader, who can then aggregate the news from different sources to synthesize a more accurate picture of reality. When newspapers are at different sides of the political spectrum, the conscientious reader gets all the facts. While individual news sources slant even more when faced with a heterogeneous public, the aggregate picture becomes more clear. In this respect, reader heterogeneity is the crucial antidote to media bias.

This analysis indicates which issues are more likely to receive accurate media coverage, at least for the conscientious reader. Almost surely, the most likely domain of reader heterogeneity is domestic politics, where readers have diverse beliefs and media coverage is correspondingly diverse. Such dispersion of reader beliefs could come from their self-interested economic and social preferences, what used to be called "class differences." But, as Glaeser (2005) argues, such differences are reinforced by political entrepreneurs, who have an incentive to create particular beliefs that would bring them support, especially if these beliefs distinguish them from the incumbent. Newspapers would then follow these entrepreneurs in mirroring and reinforcing the beliefs of their supporters. In fact, in many countries today, and in the United States 100 years ago, newspapers were affiliated with political parties (Hamilton, 2003). Reader diversity, and newspaper diversity, are partly a reflection of underlying political competition. In other areas of competition, such as sports, we likewise expect local papers to support local teams, thereby creating diversity of reporting across cities reflecting the diversity of reader beliefs.
Perhaps the clearest illustration of this corollary is the coverage of the Monica Lewinsky affair during the Clinton presidency. The leftwing press presented an enormous amount of information designed to expiate the president's sins, while the right-wing press dug out as many details pointing to his culpability. In the end, however, as Posner (1999) remarks in his book, much of the truth has come out and a conscientious reader could get a fairly complete picture of reality.

\section{Conclusion}

We have examined the roles of two forces in promoting accuracy in media: competition and reader diversity. We have found that competition by itself is not a powerful force toward accuracy. Competition forces newspapers to cater to the prejudices of their readers, and greater competition typically results in more aggressive catering to such prejudices as competitors strive to divide the market. On the other hand, we found that reader diversity is a powerful force toward accuracy, as long as accuracy is interpreted as some aggregate measure of revelation of information to a reader who takes in all the news. Greater partisanship and bias of individual media outlets may result in a more accurate picture being presented to a conscientious reader.

Reader heterogeneity comes in part from underlying political competition, whereby political parties, movements, and individual entrepreneurs attempt to generate support by presenting their points of view. If they can generate enough interest, media outlets will try to cater to the very same audiences that the political entrepreneurs attract, and diversity in media coverage will arise endogenously. In contrast, when potential audiences share similar beliefs, and when there is no advantage from political entry, such as the coverage of foreign countries or crime, we do not expect to see diversity of media reports or accuracy in media.

Political competition is only one source of underlying reader diversity. We can also imagine entrepreneurs starting newspapers on their own and, as long as they have deep enough pockets, creating enough demand for unorthodox views to broaden the range of opinions (and slants) that are being covered. Ideological diversity of entrepreneurs themselves may be the source of diversity of media coverage. 
We have studied competitive persuasion in the market for news. Our principal finding is that, when competitors can create or reinforce differences of opinion, they will do so in order to divide the market and reap higher profits. There will be no convergence in reporting to the median reader (as in a Downsian median voter framework). We believe that this consequence of competitive per- suasion is more general, and that attempts to differentiate competitively by moving toward extreme positions will arise in both political (Murphy and Shleifer, 2004) and product (Gabaix and Laibson, 2004) markets. In these and other domains, the influence of audience heterogeneity and competition on the content of persuasive messages remains to be fully explored.

ApPendix A: Lemmas

LEMMA A1: Define

$$
s_{B}(d)=\frac{\phi}{\chi+\phi}(B-d)
$$

to be the strategy where a newspaper biases around point B. The reader's expected utility (gross of price) of reading such a newspaper is:

$$
E_{d}\left[U\left(s_{B}(d)\right)\right]=\bar{u}-\frac{\chi \phi}{\chi+\phi}\left[v_{d}+b^{2}\right]-\frac{\phi^{2}}{\chi+\phi}[B-b]^{2} .
$$

Consequently when $B=0$ :

$$
E_{d}\left[U\left(s_{0}(d)\right)\right]=\bar{u}-\frac{\chi \phi}{\chi+\phi} v_{d}-\phi b^{2} .
$$

And when $B=b$ :

$$
E_{d}\left[U\left(s_{b}(d)\right)\right]=\bar{u}-\frac{\chi \phi}{\chi+\phi}\left(v_{d}+b^{2}\right) .
$$

PROOF:

Expected utility for $s_{B}(d)$ is:

$$
\bar{u}-\chi \int_{d}\left(\frac{\phi}{\chi+\phi}(B-d)\right)^{2}-\phi \int_{d}\left(d+\frac{\phi}{\chi+\phi}(B-d)-b\right)^{2} .
$$

The first integral is:

$$
-\chi\left(\frac{\phi}{\chi+\phi}\right)^{2}\left[B^{2}+v_{d}\right]
$$

because $E[d]=0$ and $E\left[d^{2}\right]=v_{d}$. The second integral is:

$$
-\phi\left[\left(\frac{\chi}{\chi+\phi}\right)^{2} v_{d}+\left(\frac{\phi}{\chi+\phi}\right)^{2} B^{2}+b^{2}-2 \frac{\phi}{\chi+\phi} B b\right]
$$

again because $E[d]=0$ and $E\left[d^{2}\right]=v_{d}$. Collecting terms produces 


$$
\begin{gathered}
\bar{u}-\frac{\phi \chi}{\chi+\phi} v_{d}-\phi b^{2}-\frac{\phi^{2}}{\chi+\phi} B^{2}+2 \frac{\phi^{2}}{\chi+\phi} B b= \\
\bar{u}-\frac{\phi \chi}{\chi+\phi}\left[v_{d}+b^{2}\right]-\phi b^{2}+\frac{\phi \chi}{\chi+\phi} b^{2}-\frac{\phi^{2}}{\chi+\phi} B^{2}+2 \frac{\phi^{2}}{\chi+\phi} B b= \\
\bar{u}-\frac{\phi \chi}{\chi+\phi}\left[v_{d}+b^{2}\right]-\frac{\phi^{2}}{\chi+\phi} b^{2}-\frac{\phi^{2}}{\chi+\phi} B^{2}+2 \frac{\phi^{2}}{\chi+\phi} B b= \\
\bar{u}-\frac{\phi \chi}{\chi+\phi}\left[v_{d}+b^{2}\right]-\frac{\phi^{2}}{\chi+\phi}\left[b^{2}+B^{2}-2 B b\right]
\end{gathered}
$$

and hence the result.

LEMMA A2: Let $x_{1} \leq x_{2}$ be the biases of two readers. For any $1 \geq c \geq 0$, the strategy

$$
s_{\bar{x}}(d)=\frac{\phi}{\chi+\phi}(\bar{x}-d)
$$

maximizes weighted average reader utility $c E_{d} u_{x_{1}}(s(d))+(1-c) E_{d} u_{x_{2}}(s(d))$, where $\bar{x}=$ $c x_{1}+(1-c) x_{2}$.

Moreover, for some $x_{1} \leq z \leq x_{2}$, the strategy $s_{z}(d)=[\phi /(\chi+\phi)](z-d)$ maximizes $\min \left\{E u_{x_{1}}(s(d)), E u_{x_{2}}(s(d))\right\}$.

\section{PROOF:}

Consider total utility $c E_{d} u_{x_{1}}(s(d))+(1-c) E_{d} u_{x_{2}}(s(d))$, which equals

$$
\int_{d}\left[\bar{u}-\chi s(d)^{2}-c \phi\left(d+s(d)-x_{1}\right)^{2}+(1-c) \phi\left(d+s(d)-x_{2}\right)^{2}\right] .
$$

Since the right-hand side shows no interdependency in $d$, maximizing this integral is equivalent to maximizing for every single $d$, the term

$$
\bar{u}-\chi s(d)^{2}-c \phi\left(d+s(d)-x_{1}\right)^{2}+(1-c) \phi\left(d+s(d)-x_{2}\right)^{2} .
$$

Taking derivatives with respect to $s$ then produces the first-order condition

$$
-2 \chi s-2 \phi(d+s-\bar{x})=0,
$$

which implies that the optimal slanting is:

$$
\frac{\phi}{\chi+\phi}(\bar{x}-d)
$$

For the second part, let $s(d)$ be a candidate slanting strategy that maximizes $\min \left\{E u_{x_{1}}(s(d))\right.$, $\left.E u_{x_{2}}(s(d))\right\}$. Define $u_{1}$ and $u_{2}$ to be the expected utilities for $s(d)$. Note that $s_{x_{1}}$ and $s_{x_{2}}$ maximize reader 1 and reader 2 utilities, respectively. Consequently, there must be a $c$ such that for $\bar{x}=c x_{1}+(1-$ c) $x_{2}$ the strategy $s_{\bar{x}}$ yields the same ratio of reader 1 and 2 utilities as the candidate strategy does: $u_{1} / u_{2}$. But by the first part of the Lemma, $E u_{i}\left(s_{\bar{x}}(d)\right) \geq u_{i}$ for $i=1,2$. Otherwise, the candidate strategy $s(d)$ would yield higher weighted average utility. But this shows $s_{\bar{x}}$ maximizes the min and hence $s=s_{\bar{x}}$. 


\section{Appendix B: Proofs of Propositions}

PROOF OF PROPOSITION 1:

Consider the monopolist's maximization problem. Reader utility is

$$
U_{r}=\max \left\{\bar{u}-\chi s^{2}-P, 0\right\} .
$$

Since readers only dislike slanting, a newspaper gets no benefit from slanting and only pays costs. The optimal strategy for both the homogeneous and heterogeneous case is therefore $s^{*}(d)=0$. Since the reader's gross utility in this case is $\bar{u}$, the monopolist can extract all surplus and charge $P$, so that the reader's net utility is 0 .

Consider now the duopoly case. Begin with the homogeneous reader case and proceed by backward induction. Consider the price setting stage. Define $V_{j}$ to be the utility the reader associates with reading newspaper $j$. There are two cases here: equal and unequal utilities. For the case of unequal utilities, suppose without loss of generality that $V_{1}>V_{2}$. The price equilibrium is for paper 1 to charge $V_{1}-V_{2}$ and capture the full market. If $V_{1}=V_{2}$, then both papers charge zero.

In the strategy-setting stage, holding constant the other's strategy, both papers' profit functions are increasing in the reader utility from the strategies they choose. Consequently, it is a weakly dominant strategy for each paper to maximize reader utility. From the monopoly case, we know these strategies are $s(d)=0$. It is an equilibrium, therefore, to have both prices and slanting equal to zero.

In the heterogeneous reader case, the logic remains the same because reader utility functions are the same as in the homogeneous case, since utility is independent of beliefs for rational readers. The homogeneous and heterogeneous cases produce the same incentives for the firm.

\section{PROOF OF PROPOSITION 2:}

Since the monopolist can extract all surplus, he maximizes expected utility,

$$
\max _{s^{*}(d)} \bar{u}-\chi \int_{d}\left(s^{*}(d)\right)^{2}-\phi \int_{d}\left(d+s^{*}(d)-b\right)^{2} .
$$

There are no interdependencies in this utility maximization across $d$ 's. Because the maximand is separable in $d$, choosing the optimal $s^{*}(d)$ is equivalent to choosing the optimal $s^{*}$ for each $d$ or

$$
s^{*}(d)=\operatorname{argmax}_{s} \bar{u}-\chi s^{2}-\phi(d+s-b)^{2} .
$$

For a given $d$, differentiating with respect to $s$ produces the first-order condition

$$
\chi s+\phi(d+s-b)=0,
$$

which implies

$$
s_{\text {hom }}^{*}(d)=\frac{\phi}{\chi+\phi}(b-d) \text {. }
$$

Prices then are equal to the expected utility under this strategy. From Lemma (A1), we know the expected utility and hence price is

$$
P_{\text {hom }}^{*}=\bar{u}-\frac{\chi \phi}{\chi+\phi}\left[b^{2}+v_{d}\right]
$$




\section{PROOF OF PROPOSITION 3:}

We proceed by backward induction. Consider the price-setting stage. Let $V_{j}$ be the reader's utility associated with reading paper $j$. There are two cases here: equal and unequal utilities. For the case of unequal utilities, suppose without loss of generality that $V_{1}>V_{2}$. The price equilibrium is for paper 1 to charge $V_{1}-V_{2}$ and capture the full market. If $V_{1}=V_{2}$, then both papers charge zero.

In the stage where the slanting strategy is set, maximizing reader utility is, as before, a weakly dominant strategy. Holding constant the other firm's strategy, each firm's profit is increasing in the reader utility associated with its strategy. We know from Proposition 2 that the utility-maximizing strategy is to slant $[\phi /(\chi+\phi)](b-d)$. Therefore, it is an equilibrium for duopolists to choose this strategy. Since this means both papers provide equal utility, prices equal zero. This shows that this is an equilibrium. Moreover, this logic directly implies that the only equilibrium involves both papers choosing a slanting strategy that maximizes utility and prices equal to zero on the equilibrium path. ${ }^{19}$

\section{PROOF OF PROPOSITION 4:}

We proceed in three steps:

(1) First, we show that a linear strategy is an optimal one.

(2) Second, we show that of the linear strategies, the strategy with zero bias produces maximum profit.

(3) Third, we compute the prices the monopolists would charge.

Step 1: Linearity of monopolist's strategy. The first step is to show that the linear strategy of the type $s_{B}(d)=[\phi /(\chi+\phi)](B-d)$ is optimal. To show this, suppose $s(d)$ and $P$ form an optimal strategy for the monopolist. Let $X=\left\{b_{i} \mid E u_{i}(s(d))-P \geq 0\right\}$ be the biases of the readers who read the paper in this case. ${ }^{20}$

Since $X \subset\left[b_{1}, b_{2}\right]$ is non-empty, it must have a well-defined inf and sup. Let $x_{1}$ and $x_{2}$ be the inf and sup of this set and $u_{1}$ and $u_{2}$ be the utility of these readers. Lemma (A2) shows that a linear strategy of the form $s_{z}(d)=[\phi /(\chi+\phi)](z-d)$, where $z=c x_{1}+(1-c) x_{2}$, maximizes $\min \left\{u_{1}\right.$, $u_{2}$ \}. So, $s_{z}$ yields the maximum payoffs for $x_{1}$ and $x_{2}$. But by Lemma (A1), all readers with bias between $x_{1}$ and $x_{2}$ have even greater utility from this strategy. Define the price $P_{z}$ to be $\min \left\{u_{1}, u_{2}\right\}$. Since $x_{1}$ and $x_{2}$ are the inf and sup of the set $X$, by the formula in Lemma (A1), it is easy to see that the strategy $s_{z}$, with price $P_{z}$, satisfies the participation constraint of all readers in $X$.

Let us now contrast the supposed optimum strategy $(s, P)$ with this strategy $\left(s_{z}, P_{z}\right)$. By construction, $s_{z}$ has at least as large a market share as $s$ since it spans all readers between the inf and sup of the set $X$. Moreover, since $s$ satisfies the participation constraint of $x_{1}$ and $x_{2}$ we know that it cannot yield higher gross utility for readers at $x_{1}$ and $x_{2}$ than $s_{z}$ does. Hence, we know that $P \leq$ $P_{z}$. Thus, the linear strategy $s_{z}(d)$ yields at least as much profit as the supposed optimum. This shows that we can work with a linear strategy as an optimum.

Step 2: Optimal bias is zero. The second step is to show that a monopolist would choose a linear strategy of $s_{B}(d)$ with $B=0$. To do this, we proceed by contradiction. Let $(B, P)$ be a linear strategy $B$ and price $P$ set by a monopolist that we suppose is an optimum strategy. Lemma (A1) shows that for a reader with bias $b$ receives utility

$$
\bar{u}-\frac{\chi \phi}{\chi+\phi}\left[v_{d}+b^{2}\right]-\frac{\phi^{2}}{\chi+\phi}[B-b]^{2}-P .
$$

\footnotetext{
${ }^{19}$ Any slanting strategy that deviates on measure zero from the optimal one also forms an equilibrium since expected utility is the same.

${ }^{20}$ This set must be non-empty since the strategy stated in the proposition earns positive profits and an empty readership would earn zero profits.
} 
All readers for whom this term is positive will read the paper. Since this is a quadratic equation, we can define the indifferent readers from this equation. By the quadratic formula, the zeros of this equation are at $z_{+}(P, B)=\left(2 B \phi+\sqrt{-4 \phi \chi B^{2}+4(K / \phi)(\chi+\phi)^{2}}\right) / 2(\chi+\phi)$ and $z_{-}(P, B)=$ $\left(2 B \phi-\sqrt{-4 \phi \chi B^{2}+4(K / \phi)(\chi+\phi)^{2}} / 2(\chi+\phi)\right.$, where $K$ is defined to be $\bar{u}-[\phi \chi /(\phi+\chi)] v_{d}-$ $P$. Of course, these zero points may lie outside the range of reader biases, so define $b_{+}(P) \doteq$ $\max \left(z_{-}(P, B), b_{1}\right)$ and $b_{-}(P)=\min \left(z_{+}(P, B), b_{2}\right)$. By definition, therefore, all individuals within this interval have weakly positive utility and therefore will purchase the paper.

With these definitions in hand, suppose now the monopolist chooses a $B \neq 0$. We will consider three different cases: (a) the case where $b_{+}$and $b_{-}$are both interior (i.e., equal to $z_{+}$and $z_{-}$); (b) the case where they are both at the boundary (i.e., equal to $b_{2}$ and $b_{1}$ ); and (c) the case where one is at the boundary and the other is at the interior. First, consider the case where $b_{+}(B, P)=z_{+}(B$, $P)$ and $b_{-}(B, P)=z_{-}(B, P)$ so that the end points are defined by the quadratic equation and not by the boundaries of the reader bias distribution. The size of the interval in this case then equals

$$
z_{+}(P)-z_{-}(P)=\frac{\sqrt{-4 \phi \chi B^{2}+4 \frac{K}{\phi}(\chi+\phi)^{2}}}{\chi+\phi} .
$$

But, since the constant $K$ does not depend on $B$, this is strictly decreasing in $B^{2}$. Hence, a $B \neq 0$ strategy cannot be optimal. If $B>0$, reducing it and keeping prices the same would increase profits, and similarly for $B<0$.

Second, consider the case where both endpoints are defined by the boundary so that $b_{+}=b_{2}<$ $z_{+}$and $b_{-}=b_{1}>z_{-}$. Let $U_{1}$ be the gross utility of the reader at the left boundary (i.e., with bias $b_{1}$ ) and $U_{2}$ be the corresponding utility for the reader at the right boundary. Prices in this case are defined by $P=\min \left\{U_{1}, U_{2}\right\}$. A price smaller than this could be increased marginally without violating the participation constraint and raising profits. A price higher than this would violate the participation constraint of the boundary readers and would be inconsistent with the definition of the boundary. Yet this price implies a violation of optimality. Lemma (A2) shows that for some $c$, choosing $B=c b_{1}+(1-c) b_{2}$ would maximize $\min \left\{U_{1}, U_{2}\right\}$. Moreover, by the symmetry of the formula in Lemma (A1) it is clear that $c=1 / 2$. So a strategy of $B=\bar{b}=0$ would still satisfy the participation constraint since it is maximizing the minimum utility. Moreover, by switching to this strategy, the monopolist could increase the price he could charge since $\min \left\{U_{1}, U_{2}\right\}$ rises. Profits also rise because he continues to cover the whole market. Hence, by switching to this strategy, the monopolist could raise profits and this contradicts $B \neq 0$ as an optimal strategy.

Third, consider the case where (without loss of generality) $b_{-}=z_{-}>b_{1}$ but $b_{+}=b_{2}<z_{+}$. By definition of the roots $z_{-}$and $z_{+}$, the reader at $b_{2}$ earns greater utility than the reader at $z_{-}$who is indifferent between buying the paper and not. But in this case, consider a deviation that leaves prices fixed but changes strategies to $B^{\prime}=B-\varepsilon$. For small enough $\varepsilon>0$, this continues to give strictly positive utility to the reader at $b_{2}$ and hence he will continue to read. This will increase market share, however, because some readers with $b<z_{-}$now earn positive utility from reading. Since this deviation increases market share without decreasing price, the original $B$ could not be an optimum.

As this includes all the cases, we have now shown that profits are maximized by a linear strategy with $B=0$. What should optimal prices look like? For $B=0$, the monopolists profits equal $P *$ $2 \sqrt{\phi} K$ where $K=\bar{u}-[\phi \chi /(\phi+\chi)] v_{d}-P$. Let $P^{m}$ be the global maximum of this function. At this maximum $b_{+}-b_{-}=2 \sqrt{\phi /\left[\bar{u}-(\chi \phi /(\chi+\phi))-P^{m}\right]}$. Define this to be $C_{m}$. So if $b_{2}-b_{1}<$ $C_{m}$, the monopolist will cover the whole market. He can then set a price equal to the utility of the boundary reader's utility, which by Lemma (A1) equals $\bar{u}-[\chi \phi /(\phi+\chi)] v_{d}-\phi^{2} b_{2}^{2}$.

\section{PROOF OF PROPOSITION 5:}

We proceed by backward induction in several steps: 
(1) We calculate $x\left(P_{1}, P_{2}, z_{1}, z_{2}\right)$, the bias of the reader who is indifferent between reading the two papers if paper $j$ charges $P_{j}$ and has bias $z_{j}$ (chosen in the first stage of the game and taken as given in this stage). This allows us to determine the market share of each firm for that location and price pair.

(2) We then calculate $P_{1}^{R}\left(P_{2} ; z_{1}, z_{2}\right)$ and $P_{2}^{R}\left(P_{1} ; z_{1}, z_{2}\right)$, the best response functions for firms 1 and 2 , respectively. These are the best price responses of each firm to the other's price (given the biases $z_{j}$ which are chosen in the first stage and taken as given in the second stage).

(3) Using these prices, we calculate the equilibrium prices $P_{1}^{*}\left(z_{1}, z_{2}\right)$ and $P_{2}^{*}\left(z_{1}, z_{2}\right)$ and market share $x^{*}\left(z_{1}, z_{2}\right)$ that result from the choice of bias in the first stage.

(4) We then use these equilibrium prices to show that in the first stage, firms will want to differentiate as long as $z_{2} \leq 3 b_{2}$. We show that at $z_{2}=3 b_{2}$ and $z_{1}=3 b_{1}=-3 b_{2}$, the firms are indifferent between lowering and raising $z_{j}$ and thus in equilibrium.

(5) Finally, we show that all participation constraints for the consumer are satisfied at the equilibrium.

Step 1: Calculating $x\left(P_{1}, P_{2} ; z_{1}, z_{2}\right)$. A reader with bias $x$ receives utility:

$$
\bar{u}-\frac{\chi \phi}{\chi+\phi}\left[v_{d}+x^{2}\right]-\frac{\phi^{2}}{\chi+\phi}\left[z_{j}-x\right]^{2}-P_{j}
$$

from reading paper $j$ (Lemma (A1)). If the reader with bias $x$ is indifferent between these two papers, then the utilities from reading the two papers are equal:

$\bar{u}-\frac{\chi \phi}{\chi+\phi}\left[v_{d}+x^{2}\right]-\frac{\phi^{2}}{\chi+\phi}\left[z_{2}-x\right]^{2}-P_{2}=\bar{u}-\frac{\chi \phi}{\chi+\phi}\left[v_{d}+x^{2}\right]-\frac{\phi^{2}}{\chi+\phi}\left[z_{1}-x\right]^{2}-P_{1}$.

This equality can in turn be simplified to

$$
\begin{aligned}
\frac{\phi^{2}}{\chi+\phi}\left[\left(z_{1}-x\right)^{2}-\left(z_{2}-x\right)^{2}\right] & =P_{2}-P_{1} \\
\frac{\phi^{2}}{\chi+\phi}\left(z_{2}-z_{1}\right)\left[2 x-\left(z_{2}+z_{1}\right)\right] & =P_{2}-P_{1} \\
\frac{2 \phi^{2}}{\chi+\phi} \Delta z[x-\bar{z}] & =\Delta P \\
x\left(P_{1}, P_{2} ; z_{1}, z_{2}\right) & =\bar{z}+\frac{\Delta P}{\Delta z} \frac{\chi+\phi}{2 \phi^{2}}
\end{aligned}
$$

where $\bar{z}=\left(z_{1}+z_{2}\right) / 2, \Delta P=P_{2}-P_{1}$, and $\Delta z=z_{2}-z_{1}$.

Step 2: Calculation price best response functions $P_{j}^{R}\left(P_{-j}\right)$. Since the indifferent reader is located at $x$, firm profits are given by

$$
\Pi_{1}\left(P_{1}, P_{2} ; z_{1}, z_{2}\right)=\frac{P_{1}}{b_{2}-b_{1}}\left(x-b_{1}\right)
$$




$$
\Pi_{2}\left(P_{1}, P_{2} ; z_{1}, z_{2}\right)=\frac{P_{1}}{b_{2}-b_{1}}\left(b_{2}-x\right) .
$$

The firm's best price response can be derived by differentiating profits with respect to own price. For firm 1, this first-order condition is

$$
\begin{aligned}
\frac{1}{b_{2}-b_{1}}\left[x-b_{1}+P_{1} \frac{\partial x_{1}}{\partial P_{1}}\right] & =0 \\
x-b_{1}+P_{1} \frac{\partial x_{1}}{\partial P_{1}} & =0 \\
\bar{z}+\frac{\Delta P}{\Delta z} \frac{\chi+\phi}{2 \phi^{2}}-b_{1}+P_{1}\left(-\frac{\chi+\phi}{2 \phi^{2} \Delta z}\right) & =0 \\
\bar{z}+\frac{P_{2}}{\Delta z} \frac{\chi+\phi}{2 \phi^{2}}-b_{1} & =P_{1} \frac{\chi+\phi}{\phi^{2} \Delta z} \\
\left(\bar{z}-b_{1}\right) \frac{\Delta z \phi^{2}}{\chi+\phi}+\frac{P_{2}}{2} & =P_{1} .
\end{aligned}
$$

So the best response function is

$$
P_{1}^{R}\left(P_{2} ; z_{1}, z_{2}\right)=\frac{P_{2}}{2}+\left(b_{2}+\bar{z}\right) \frac{\Delta z \phi^{2}}{\chi+\phi}
$$

where we've used the fact that $b_{2}=-b_{1}$ by assumption. Similarly, the best response function for firm 2 is

$$
P_{2}^{R}\left(P_{1} ; z_{1}, z_{2}\right)=\frac{P_{1}}{2}+\left(b_{2}-\bar{z}\right) \frac{\Delta z \phi^{2}}{\chi+\phi} .
$$

Step 3: Calculating equilibrium prices and market share. The Nash equilibrium of prices can be calculated from the best response functions by solving

$$
\begin{aligned}
& P_{1}^{*}=P_{1}^{R}\left(P_{2}^{R}\left(P_{1}^{*} ; z_{1}, z_{2}\right)\right) \\
& P_{2}^{*}=P_{2}^{R}\left(P_{1}^{R}\left(P_{2}^{*} ; z_{1}, z_{2}\right)\right) .
\end{aligned}
$$

The first equation can be calculated as follows:

$$
\begin{aligned}
& P_{1}^{*}=P_{1}^{R}\left(P_{2}^{R}\left(P_{1}^{*} ; z_{1}, z_{2}\right)\right) \\
& P_{1}^{*}=\frac{P_{2}^{R}\left(P_{1}^{*} ; z_{1}, z_{2}\right)}{2}+\left(b_{2}+\bar{z}\right) \frac{\Delta z \phi^{2}}{\chi+\phi} \\
& P_{1}^{*}=\frac{1}{2}\left(\frac{P_{1}}{2}+\left(b_{2}+\bar{z}\right) \frac{\Delta z \phi^{2}}{\chi+\phi}\right)+\left(b_{2}+\bar{z}\right) \frac{\Delta z \phi^{2}}{\chi+\phi}
\end{aligned}
$$




$$
\begin{aligned}
\frac{3}{4} P_{1}^{*} & =\frac{\phi^{2} \Delta z}{\chi+\phi}\left[\frac{b_{2}}{2}-\frac{\bar{z}}{2}+\bar{z}+b_{2}\right] \\
P_{1}^{*} & =\frac{\phi^{2} \Delta z}{\chi+\phi}\left[2 b_{2}+\frac{2 \bar{z}}{3}\right]
\end{aligned}
$$

By a similar calculation

$$
P_{2}^{*}=\frac{\phi^{2} \Delta z}{\chi+\phi}\left[2 b_{2}-\frac{2 \bar{z}}{3}\right]
$$

Using these equilibrium prices, we can also calculate equilibrium market share as

$$
\begin{aligned}
& x *\left(z_{1}, z_{2}\right)=\bar{z}+\Delta P \frac{\chi+\phi}{2 \phi^{2} \Delta z} \\
& x *\left(z_{1}, z_{2}\right)=\bar{z}+\left[-\frac{4 \bar{z}}{3} \frac{\phi^{2} \Delta z}{\chi+\phi}\right] \frac{\chi+\phi}{2 \phi^{2} \Delta z} \\
& x *\left(z_{1}, z_{2}\right)=\bar{z}-\bar{z} \frac{2}{3} \\
& x^{*}\left(z_{1}, z_{2}\right)=\frac{\bar{z}}{3}
\end{aligned}
$$

Step 4: Differentiation in choosing bias (the first stage). These prices and market share allow us to backward induct and examine the firm's decision in stage 1. Taking the other firm's bias as given, they can be used to calculate each firm's profits for each bias chosen. Specifically profits in stage 1 are

$$
\begin{aligned}
& \Pi_{1}\left(z_{1}, z_{2}\right)=P_{1}^{*}\left(z_{1}, z_{2}\right)\left[x^{*}\left(z_{1}, z_{2}\right)-b_{1}\right] \\
& \Pi_{2}\left(z_{1}, z_{2}\right)=P_{2}^{*}\left(z_{1}, z_{2}\right)\left[b_{2}-x^{*}\left(z_{1}, z_{2}\right)\right] .
\end{aligned}
$$

The first-order condition for this problem is instructive. Focusing on firm 1, we can write profits as

$$
P_{1}^{*}\left(z_{1}, z_{2}\right)\left[\frac{\bar{z}}{3}-b_{1}\right] .
$$

Differentiating with respect to $z_{1}$ gives

$$
\begin{aligned}
& \frac{\partial \Pi_{1}}{\partial z_{1}}=\frac{P_{1}^{*}\left(z_{1}, z_{2}\right)}{6}+\frac{\partial P_{1}^{*}\left(z_{1}, z_{2}\right)}{\partial z_{1}}\left[\frac{\bar{z}}{3}-b_{1}\right] \\
& \frac{\partial \Pi_{1}}{\partial z_{1}}=\left(b_{2}+\frac{\bar{z}}{3}\right) \frac{2 \phi^{2} \Delta z}{6(\chi+\phi)}+\left(b_{2}+\frac{\bar{z}}{3}\right) \frac{2 \phi^{2}}{\chi+\phi}\left[\frac{\Delta z}{6}-b_{2}-\frac{\bar{z}}{3}\right] .
\end{aligned}
$$


Now we are interested in the sign of this derivative. Define $\operatorname{sign}(x)$ to be the function that equals +1 if $x>0$ and -1 if $x<0$. We can then write

$$
\begin{aligned}
& \operatorname{sign}\left(\frac{\partial \Pi_{1}}{\partial z_{1}}\right)=\operatorname{sign}\left(\left(b_{2}+\frac{\bar{z}}{3}\right) \Delta z+\left(b_{2}+\frac{\bar{z}}{3}\right) *\left[\Delta z-6 b_{2}-2 \bar{z}\right]\right) \\
& \operatorname{sign}\left(\frac{\partial \Pi_{1}}{\partial z_{1}}\right)=\operatorname{sign}\left(\left[b_{2}+\frac{\bar{z}}{3}\right] *\left(\Delta z+\Delta z-6 b_{2}-2 \bar{z}\right)\right) .
\end{aligned}
$$

Now suppose that we are in a symmetric case where $z_{1}=-z_{2}$ so that $\bar{z}=0$. In this case,

$$
\begin{aligned}
& \operatorname{sign}\left(\left.\frac{\partial \Pi_{1}}{\partial z_{1}}\right|_{\bar{z}=0}\right)=\operatorname{sign}\left(b_{2} *\left(2 \Delta z-6 b_{2}\right)\right) \\
& \left.\operatorname{sign}\left(\left.\frac{\partial \Pi_{1}}{\partial z_{1}}\right|_{\bar{z}=0}\right)=\operatorname{sign}\left(2 \Delta z-6 b_{2}\right)\right) \\
& \left.\operatorname{sign}\left(\left.\frac{\partial \Pi_{1}}{\partial z_{1}}\right|_{\bar{z}=0}\right)=\operatorname{sign}\left(-4 z_{1}-6 b_{2}\right)\right) .
\end{aligned}
$$

So $\left.\left(\partial \Pi_{1} / \partial z_{1}\right)\right|_{\bar{z}=0}<0$ if and only if $-2 z_{1}<3 b_{2}$. In other words, if $-z_{1}<3 / 2 b_{2}$, firm 1 always has an incentive to further lower $z_{1}$. If $-z_{1}>3 / 2 b_{2}$, firm 1 has an incentive to raise $z_{1}$. A similar derivation shows that $\left.\left(\partial \Pi_{2} / \partial z_{2}\right)\right|_{\bar{z}=0}>0$ only if $z_{2}<3 / 2 b_{2}$. This, therefore, shows that at $z_{2}^{*}=$ $3 / 2 b_{2}$ and $z_{1}^{*}=-3 / 2 b_{2}$, the firms are at a Nash equilibrium for the first stage game. Substitution shows that for this choice of $z_{j}^{*}$, prices must be equal to $\left[\phi^{2} /(\chi+\phi)\right] 6 b_{2}^{2}$.

Step 5: Boundary conditions. Finally, we must verify that in equilibrium, the participation constraints of the consumer are satisfied. It suffices to show that the consumer located at zero receives non-zero utility from buying either paper. That is, we must show (by Lemma (1)) that:

$$
\bar{u}-\frac{\chi \phi}{\phi+\chi} v_{d}-\frac{\phi^{2}}{\chi+\phi} \frac{9}{4} b_{2}^{2}-6 \frac{\phi^{2}}{\chi+\phi} b_{2}^{2}>0
$$

where the first three terms are the gross utility of reading the paper and the last term is the price. This is equivalent to:

$$
\frac{33}{4} b_{2}^{2} \frac{\phi^{2}}{\chi+\phi}<\bar{u}-\frac{\phi \chi}{\chi+\phi} v_{d},
$$

which is equivalent to

$$
b_{2}<\sqrt{\frac{4}{33}\left[\frac{\phi+\chi}{\phi^{2}} \bar{u}-\frac{\chi}{\phi} v_{d}\right]}
$$

which is what was assumed in the statement of the proposition. 


\section{PROOF OF COROLLARY 4:}

Consider the first comparison: $\mathrm{CRB}_{\text {het,duo }}<\mathrm{CRB}_{\text {het,mon }}$. From Propositions 5 and 4 , we know that duopolists report more diverse news than the monopolist when readers are heterogeneous. But from the functional form of $\mathrm{xc}(\cdot, \cdot)$, we know that this diversity allows the conscientious reader to cross-check and thus produces less bias for her overall.

Consider the second comparison $\mathrm{CRB}_{\text {het,duo }}<\mathrm{CRB}_{\text {hom,duo }}$. By Propositions 5 and 3, we know that reporting in the heterogeneous case is more diverse. So, once again, the increased diversity means lower conscientious reader bias.

\section{REFERENCES}

Alterman, Eric. What liberal media? The truth about bias and the news. New York: Basic Books, 2003.

Baron, David. "Persistent Media Bias." Stanford University, Graduate School of Business Research Papers: No. 1845, 2004.

Bartlett, Frederic. Remembering: A study in experimental and social psychology. Cambridge: Cambridge University Press, 1932.

- Besley, Timothy and Burgess, Robin. "The Political Economy of Government Responsiveness: Theory and Evidence from India." Quarterly Journal of Economics, 2002, 117(4), pp. 1415-51.

Besley, Timothy and Prat, Andrea. "Handcuffs for the Grabbing Hand? Media Capture and Government Accountability." Center for Economic Policy Research, CEPR Discussion Papers: No. 3132, 2002.

Brenner, Steffen. "Determinants of Product Differentiation: A Survey." Unpublished Paper, 2001.

-Brunnermeier, Markus K. and Nagel, Stefan. "Hedge Funds and the Technology Bubble." Journal of Finance, 2004, 59(5), pp. 2013-40.

Coase, Ronald H. "The Market for Goods and the Market for Ideas." American Economic Review, 1974, 64(2), pp. 384-91.

Coulter, Ann. Slander: Liberal lies about the American Right. New York: Three Rivers Press, 2003.

d'Aspremont, Claude; Gabszewicz, Jean J. and Thisse, Jacque-Francois. "On Hotelling's 'Stability in Competition'.” Econometrica, 1979, 47(5), pp. 1145-50.

De Long, J. Bradford; Shleifer, Andrei; Summers, Lawrence H. and Waldmann, Robert J. "Positive Feedback Investment Strategies and Destabilizing Rational Speculation." Journal of Finance, 1990, 45(2), pp. 379-95.

Djankov, Simeon; McLiesh, Carlee; Nenova, Tatiana and Shleifer, Andrei. "Who Owns the
Media?" Journal of Law and Economics, 2003, 46(2), pp. 341-81.

Dyck, Alexander and Zingales, Luigi. "The Corporate Governance Role of the Media," in Roumeen Islam, ed., The right to tell: The role of media in development. Washington, DC: 2002, pp. 107-37.

Economides, Nicholas. "Minimal and Maximal Product Differentiation in Hotelling's Duopoly." Economics Letters, 1986, 21(1), pp. 67-71.

Fiske, Susan. "Social Cognition," in Abraham Tesser, ed., Advanced social psychology. New York: McGraw-Hill, 1995.

Franken, Al. Lies and the lying liars who tell them: A fair and balanced look at the Right. New York: E.P. Dutton \& Company, 2003.

Friedman, Milton. "The Case for Flexible Exchange Rates," in Milton Friedman, ed., Essays in positive economics. Chicago: University of Chicago Press, 1953, pp. 157203.

Gabaix, Xavier and Laibson, David. "Shrouded Attributes and Information Suppression in Competitive Markets." Unpublished Paper, 2004.

Gabszewicz, Jean J.; Laussel, Dider and Sonnac, Nathalie. "Press Advertising and the Ascent of the 'Pensee Unique'." European Economic Review, 2001, 45(4-6), pp. 641-51.

Gal-Or, Esther and Dukes, Anthony. "Minimum Differentiation in Commercial Media Markets." Journal of Economics and Management Strategy, 2003, 12(3), pp. 291-325.

-Gentzkow, Matthew A. and Shapiro, Jesse M. "Media, Education and Anti-Americanism in the Muslim World." Journal of Economic Perspectives, 2004, 18(3), pp. 117-33.

- Glaeser, Edward L. "The Political Economy of Hatred." Quarterly Journal of Economics, 2005, 120(1), pp. 45-86.

Goettler, Ronald L. and Shachar, Ron. "Spatial Competition in the Network Television Industry." RAND Journal of Economics, 2001, 32(4), pp. 624-56. 
Goldberg, Bernard. Bias: A CBS insider exposes how the media distort the news. Washington, DC: Regency Publishing, Inc., 2002.

Graber, Doris. Processing the news: How people tame the information tide. New York: Longman Press, 1984.

Hamilton, James T. All the news that's fit to sell: How the market transforms information into news. Princeton: Princeton University Press, 2003.

Hayakawa, Samuel I. Language in thought and action, 5th ed. New York: Harcourt, Brace \& Company, 1990. First published in 1940 by Harcourt, Brace \& Company.

Jensen, Michael. "Toward a Theory of the Press," in Karl Brunner, ed., Economics and social institutions: Insights from the conferences on analysis and ideology. Boston: Martinus Nijhoff Publishing, 1979.

Klayman, Josh. "Varieties of Confirmation Bias," in Jerome Busemeyer, Reud Hastie and Douglas Medin, eds., Decision making from a cognitive perspective. The psychology of learning and motivation. Vol. 32. San Diego: Academic Press, 1995, pp. 365-418.

Kull, Steven, et al. "Misperceptions, the Media and the Iraq War," Program on International Policy Attitudes, http://www.pipa.org, 2003.

Lippmann, Walter. Public opinion. 1922. Reprint, New York: Free Press, 1965.

-Lord, Charles G.; Ross, Lee and Lepper, Mark R. "Biased Assimilation and Attitude Polarization: The Effect of Theories on Subsequently Considered Evidence." Journal of Personality and Social Psychology, 1979, 37(11), pp. 2098-109.

Mencken, Henry L. A gang of pecksniffs. 1920.
Reprint, New Rochelle, NY: Arlington House Publishers, 1975.

Mullainathan, Sendhil. "Thinking through Categories." Unpublished Paper, 2002.

Murphy, Kevin M. and Shleifer, Andrei. "Persuasion in Politics." American Economic Review, 2004, (Papers and Proceedings), 94(2), pp. 435-39.

Posner, Richard A. An affair of state: The investigation, impeachment, and trial of President Clinton. Cambridge, MA: Harvard University Press, 1999.

- Rabin, Matthew and Schrag, Joel L. "First Impressions Matter: A Model of Confirmatory Bias." Quarterly Journal of Economics, 1999, 114(1), pp. 37-82.

Severin, Werner J. and Tankard, James W., Jr. Communication theories: Origins, methods and uses in the mass media, 3rd ed. New York: Longman Group, Ltd., 1992.

Shleifer, Andrei. Inefficient markets: An introduction to behavioral finance. Oxford: Oxford University Press, 2000.

Spence, A. Michael and Owen, Bruce. "Television Programming, Monopolistic Competition, and Welfare." Quarterly Journal of Economics, 1977, 91(1), pp. 103-26.

-Steiner, Peter. "Program Patterns and Preferences, and the Workability of Competition in Radio Broadcasting." Quarterly Journal of Economics, 1952, 66(2), pp. 194-223.

Stromberg, David. "Mass Media and Public Policy." European Economic Review, 2001, 45(4-6), pp. 652-63.

Tirole, Jean. The theory of industrial organization. Cambridge, MA: MIT Press, 1988.

Zaller, John R. The nature and origins of mass opinion. Cambridge: Cambridge University Press, 1992. 


\section{This article has been cited by:}

1. Riccardo Ferretti, Andrea Cipollini, Francesco Pattarin, David McMillan. 2016. Can an unglamorous nonevent affect prices? The role of newspapers. Cogent Economics \& Finance 4, 1142847. [CrossRef]

2. Tanya Filer, Rolf Fredheim. 2016. Sparking debate? Political deaths and Twitter discourses in Argentina and Russia. Information, Communication \& Society 19:11, 1539-1555. [CrossRef]

3. Maxwell Winchester, Gavin Lees. 2016. An Investigation of the Success of Targeting Newspapers and Efficiency of Advertising in Ireland. Journal of Promotion Management 1-17. [CrossRef]

4. Nitish Ranjan Sinha. 2016. Underreaction to News in the US Stock Market. Quarterly Journal of Finance 06:02, 1650005. [CrossRef]

5. Homero Gil de Zúñiga, Trevor Diehl, Alberto Ardèvol-Abreu. 2016. When Citizens and Journalists Interact on Twitter. Journalism Studies 1-20. [CrossRef]

6. Archishman Chakraborty, Parikshit Ghosh. 2016. Character Endorsements and Electoral Competition. American Economic Journal: Microeconomics 8:2, 277-310. [Abstract] [View PDF article] [PDF with links]

7. Stefan Hielscher, Ingo Pies, Vladislav Valentinov, Lioudmila Chatalova. 2016. Rationalizing the GMO Debate: The Ordonomic Approach to Addressing Agricultural Myths. International Journal of Environmental Research and Public Health 13:5, 476. [CrossRef]

8. Ivan Medovikov. 2016. When does the stock market listen to economic news? New evidence from copulas and news wires. Journal of Banking \& Finance 65, 27-40. [CrossRef]

9. Seok Ho Lee. 2016. When ideology meets bottom line: analysis on market competition and ideological bias in newspapers. Asian Journal of Communication 1-20. [CrossRef]

10. Brinja Meiseberg, Thomas Ehrmann, Jochen Lengers. 2016. Quality kills the mediastar? Career paths of intellectuals. Journal of Business Economics . [CrossRef]

11. Xing Lu, Hunter M Holzhauer, Jun Wang. 2016. Online Search Frequency, Information Asymmetry, and Market Liquidity. The Journal of Index Investing 6, 71-81. [CrossRef]

12. Christian Bruns, Oliver Himmler. 2016. Mass media, instrumental information, and electoral accountability. Journal of Public Economics 134, 75-84. [CrossRef]

13. Kyu S. Hahn, Hye-Yon Lee, Jihye LeeMedia Bias 1-9. [CrossRef]

14. Brinja Meiseberg, Jochen Lengers, Thomas Ehrmann. 2016. The Economics of Sensationalism: The Lack of Effect of Scandal-Reporting on Business Outcomes. Journal of Media Economics 29, 4-15. [CrossRef]

15. Devra Moehler, Douglas Michael Allen. 2016. The Media Diet Imbalance Score: A Measure of Aggregate Media Diet. Communication Methods and Measures 10, 4-12. [CrossRef]

16. Chongwoo Choe, Paul A. Raschky. 2016. Media, institutions, and government action: Prevention vs. palliation in the time of cholera. European Journal of Political Economy 41, 75-93. [CrossRef]

17. Ceren Budak, Sharad Goel, Justin M. Rao. 2016. Fair and Balanced? Quantifying Media Bias through Crowdsourced Content Analysis. Public Opinion Quarterly 80, 250-271. [CrossRef]

18. Joshua P. Darr. 2015. Presence to Press: How Campaigns Earn Local Media. Political Communication 1-20. [CrossRef]

19. Devin G. Pope, Justin R. SydnorBehavioral Economics 800-827. [CrossRef]

20. Oliver Latham. 2015. Lame Ducks and the Media. The Economic Journal 125:10.1111/ ecoj.2015.125.issue-589, 1918-1951. [CrossRef]

21. Alberto Bayo-Moriones, Cristina Etayo, Alfonso Sánchez-Tabernero. 2015. Political orientation and perceived quality of television channels. Journal of Service Theory and Practice 25, 813-835. [CrossRef]

22. Man ZHANG, Hui QIAO, Xu WANG, Ming-zhe PU, Zhi-jun YU, Feng-tian ZHENG. 2015. The third-party regulation on food safety in China: A review. Journal of Integrative Agriculture 14, 2176-2188. [CrossRef] 
23. Anthony M. Bertelli, J. Andrew Sinclair. 2015. Mass Administrative Reorganization, Media Attention, and the Paradox of Information. Public Administration Review 75:6, 855-866. [CrossRef]

24. Hamza Bennani. 2015. The Euro Area, a Stressful Monetary Union? Learning from Newspapers' Monetary Policy Coverage. Journal of Economic Issues 49, 1008-1027. [CrossRef]

25. Maria Rosa Battaggion, Alessandro Vaglio. 2015. Pin-ups and Journalists: A Model of Media Market with News and Entertainment. Journal of Media Economics 28, 217-245. [CrossRef]

26. Bernd Hayo, Matthias Neuenkirch. 2015. Self-monitoring or reliance on media reporting: How do financial market participants process central bank news?. Journal of Banking \& Finance 59, 27-37. [CrossRef]

27. Amedeo Piolatto, Florian Schuett. 2015. Media competition and electoral politics. Journal of Public Economics 130, 80-93. [CrossRef]

28. Steven F. Cahan, Chen Chen, Li Chen, Nhut H. Nguyen. 2015. Corporate social responsibility and media coverage. Journal of Banking \& Finance 59, 409-422. [CrossRef]

29. Santiago Oliveros, Felix Várdy. 2015. Demand for Slant: How Abstention Shapes Voters' Choice of News Media. The Economic Journal 125:10.1111/ecoj.2015.125.issue-587, 1327-1368. [CrossRef]

30. Ascensión Andina-Díaz. 2015. Competition and uncertainty in a paper's news desk. Journal of Economics 116, 77-93. [CrossRef]

31. Marco Gambaro, Riccardo Puglisi. 2015. What do ads buy? Daily coverage of listed companies on the Italian press. European Journal of Political Economy 39, 41-57. [CrossRef]

32. Fernanda Leite Lopez de Leon. 2015. Endorse or Not to Endorse: Understanding the Determinants of Newspapers' Likelihood of Making Political Recommendations. Scottish Journal of Political Economy n/ a-n/a. [CrossRef]

33. David Strömberg. 2015. Media and Politics. Annual Review of Economics 7, 173-205. [CrossRef]

34. Fei Shen, Tianjiao Wang. 2015. Does perceived incongruence in opinion climate influence the degree of outspokenness? Evidence from two national events in China. Chinese Journal of Communication 8, 253-271. [CrossRef]

35. K. R. Ahern, D. Sosyura. 2015. Rumor Has It: Sensationalism in Financial Media. Review of Financial Studies 28, 2050-2093. [CrossRef]

36. Benjamin Ho, Peng Liu. 2015. Herd journalism: Investment in novelty and popularity in markets for news. Information Economics and Policy 31, 33-46. [CrossRef]

37. Aniruddha Mitra, James T. Bang, Arnab Biswas. 2015. Media freedom and gender equality: a crossnational instrumental variable quantile analysis. Applied Economics 47, 2278-2292. [CrossRef]

38. Qiuqing Tai. 2015. Western Media Exposure and Chinese Immigrants' Political Perceptions. Political Communication 1-20. [CrossRef]

39. Mehdi Shadmehr, Dan Bernhardt. 2015. State Censorship. American Economic Journal: Microeconomics 7:2, 280-307. [Abstract] [View PDF article] [PDF with links]

40. Wen-Chung Guo, Fu-Chuan Lai. 2015. Media bias, slant regulation, and the public-interest media. Journal of Economics 114, 291-308. [CrossRef]

41. Arye L. Hillman, Niklas Potrafke. 2015. The UN Goldstone Report and retraction: an empirical investigation. Public Choice . [CrossRef]

42. Stefan Behringer, Lapo Filistrucchi. 2015. Hotelling competition and political differentiation with more than two newspapers. Information Economics and Policy 30, 36-49. [CrossRef]

43. Jill J. McCluskey, Johan Swinnen, Thijs Vandemoortele. 2015. You get what you want: A note on the economics of bad news. Information Economics and Policy 30, 1-5. [CrossRef]

44. Ralf Dewenter, Ulrich Heimeshoff. 2015. Do expert reviews really drive demand? Evidence from a German car magazine. Applied Economics Letters 1-4. [CrossRef] 
45. Andrei Shleifer. 2015. Matthew Gentzkow, Winner of the 2014 Clark Medal. Journal of Economic Perspectives 29:1, 181-192. [Abstract] [View PDF article] [PDF with links]

46. Matthew Gentzkow, Nathan Petek, Jesse M. Shapiro, Michael Sinkinson. 2015. DO NEWSPAPERS SERVE THE STATE? INCUMBENT PARTY INFLUENCE ON THE US PRESS, 1869-1928. Journal of the European Economic Association 13:10.1111/jeea.2015.13.issue-1, 29-61. [CrossRef]

47. Yi Zhu, Anthony Dukes. 2015. Selective Reporting of Factual Content by Commercial Media. Journal of Marketing Research 52, 56-76. [CrossRef]

48. NICOLA GENNAIOLI, ANDREI SHLEIFER, ROBERT VISHNY. 2015. Money Doctors. The Journal of Finance 70:10.1111/jofi.2015.70.issue-1, 91-114. [CrossRef]

49. Ralf Dewenter, Ulrich Heimeshoff. 2015. More ads more revs: A note on media bias in review likelihood. Economic Modelling 44, 156-161. [CrossRef]

50. Ora John Reuter, David Szakonyi. 2015. Online Social Media and Political Awareness in Authoritarian Regimes. British Journal of Political Science 45, 29-51. [CrossRef]

51. Jacob Cherian. 2015. Emergence of Digital Publishing - A Great Challenge to The Print Publications. Procedia Economics and Finance 23, 576-586. [CrossRef]

52. Matthias W Uhl, Mads Pedersen, Oliver Malitius. 2015. What's in the News? Using News Sentiment Momentum for Tactical Asset Allocation. The Journal of Portfolio Management 41, 100-112. [CrossRef]

53. Michael J. Lamla, Sarah M. Lein. 2015. INFORMATION RIGIDITIES, INFLATION PERCEPTIONS, AND THE MEDIA: LESSONS FROM THE EURO CASH CHANGEOVER. Economic Inquiry 53:1, 9. [CrossRef]

54. Maria Rosa Battaggion, Alessandro Vaglio. 2015. Watchdogs, Platforms and Audience: An Economic Perspective on Media Markets. Atlantic Economic Journal 43:2, 209. [CrossRef]

55. A. M. Guess. 2015. Measure for Measure: An Experimental Test of Online Political Media Exposure. Political Analysis 23, 59-75. [CrossRef]

56. Paul C. Tetlock. 2014. Information Transmission in Finance. Annual Review of Financial Economics 6, 365-384. [CrossRef]

57. Marcel Garz. 2014. Good news and bad news: evidence of media bias in unemployment reports. Public Choice 161, 499-515. [CrossRef]

58. Guido Friebel, Matthias Heinz. 2014. Media slant against foreign owners: Downsizing. Journal of Public Economics 120, 97-106. [CrossRef]

59. Jayson L. Lusk, Jutta Roosen, Andrea Bieberstein. 2014. Consumer Acceptance of New Food Technologies: Causes and Roots of Controversies. Annual Review of Resource Economics 6, 381-405. [CrossRef]

60. D. Yanagizawa-Drott. 2014. Propaganda and Conflict: Evidence from the Rwandan Genocide. The Quarterly Journal of Economics 129, 1947-1994. [CrossRef]

61. Maria Arango-Kure, Marcel Garz, Armin Rott. 2014. Bad News Sells: The Demand for News Magazines and the Tone of Their Covers. Journal of Media Economics 27, 199-214. [CrossRef]

62. Matthias W. Uhl. 2014. Reuters Sentiment and Stock Returns. Journal of Bebavioral Finance 15, 287-298. [CrossRef]

63. Matthew Gentzkow, Jesse M. Shapiro, Michael Sinkinson. 2014. Competition and Ideological Diversity: Historical Evidence from US Newspapers. American Economic Review 104:10, 3073-3114. [Abstract] [View PDF article] [PDF with links]

64. Sanghamitra BandyopadhyayAre Mass Media and ICTs Associated with Inequality and Poverty? 185-216. [CrossRef]

65. Matthias Neuenkirch. 2014. Federal Reserve communications and newswire coverage. Applied Economics 46, 3119-3129. [CrossRef] 
66. Armando J. Garcia Pires. 2014. Media diversity, advertising, and adaptation of news to readers' political preferences. Information Economics and Policy 28, 28-38. [CrossRef]

67. Thomas Hills, Elad Segev. 2014. The news is American but our memories are ... Chinese?. Journal of the Association for Information Science and Technology 65:10.1002/asi.2014.65.issue-9, 1810-1819. [CrossRef]

68. Vincent Bignon, Marc Flandreau. 2014. The Price of Media Capture and the Debasement of the French Newspaper Industry During the Interwar. The Journal of Economic History 74, 799-830. [CrossRef]

69. Filipe R. Campante, Quoc-Anh Do. 2014. Isolated Capital Cities, Accountability, and Corruption: Evidence from US States. American Economic Review 104:8, 2456-2481. [Abstract] [View PDF article] [PDF with links]

70. James N. Druckman. 2014. Pathologies of Studying Public Opinion, Political Communication, and Democratic Responsiveness. Political Communication 31, 467-492. [CrossRef]

71. Wen-Chung Guo, Fu-Chuan Lai. 2014. Media Bias When Advertisers Have Bargaining Power. Journal of Media Economics 27, 120-136. [CrossRef]

72. Jiao Xu, Chris Forman, Jun B. Kim, Koert Van Ittersum. 2014. News Media Channels: Complements or Substitutes? Evidence from Mobile Phone Usage. Journal of Marketing 78, 97-112. [CrossRef]

73. John R. Lott, Kevin A. Hassett. 2014. Is newspaper coverage of economic events politically biased?. Public Choice 160, 65-108. [CrossRef]

74. Robert J. Shiller. 2014. Speculative Asset Prices. American Economic Review 104:6, 1486-1517. [Citation] [View PDF article] [PDF with links]

75. Andrew Caplin, Roy Lowrance. 2014. The Mortgage Mess, the Press, and the Politics of Inattention. American Economic Review 104:5, 77-81. [Abstract] [View PDF article] [PDF with links]

76. Francesco Sobbrio. 2014. Citizen-editors' endogenous information acquisition and news accuracy. Journal of Public Economics 113, 43-53. [CrossRef]

77. Matthew Pinnuck. 2014. The New York Times and Wall Street Journal : Does Their Coverage of Earnings Announcements Cause "Stale" News to Become "New" News?. Journal of Bebavioral Finance 15, 120-132. [CrossRef]

78. Elena Kulchina. 2014. Media coverage and location choice. Strategic Management Journal 35:10.1002/ smj.2014.35.issue-4, 596-605. [CrossRef]

79. Pinar Yildirim, Esther Gal-Or, Tansev Geylani. 2013. User-Generated Content and Bias in News Media. Management Science 59, 2655-2666. [CrossRef]

80. Yi Xiang, David Soberman. 2013. Consumer Favorites and the Design of News. Management Science 131105054351001. [CrossRef]

81. Monic Sun, Feng Zhu. 2013. Ad Revenue and Content Commercialization: Evidence from Blogs. Management Science 59, 2314-2331. [CrossRef]

82. Stuart Soroka, Blake Andrew, Toril Aalberg, Shanto Iyengar, James Curran, Sharon Coen, Kaori Hayashi, Paul Jones, Gianpetro Mazzoleni, June Woong Rhee, David Rowe, Rod Tiffen. 2013. Auntie Knows Best? Public Broadcasters and Current Affairs Knowledge. British Journal of Political Science 43, 719-739. [CrossRef]

83. Matthew Levendusky. 2013. Partisan Media Exposure and Attitudes Toward the Opposition. Political Communication 30, 565-581. [CrossRef]

84. 2013. Mezzi di comunicazione di massa e pluralismo: un approccio economico. ECONOMIA E POLITICA INDUSTRIALE 43-69. [CrossRef]

85. Jimmy Chan, Daniel F. Stone. 2013. Media proliferation and partisan selective exposure. Public Choice 156, 467-490. [CrossRef]

86. Hiroyuki Aman. 2013. An analysis of the impact of media coverage on stock price crashes and jumps: Evidence from Japan. Pacific-Basin Finance Journal 24, 22-38. [CrossRef] 
87. KENNETH R. AHERN, DENIS SOSYURA. 2013. Who Writes the News? Corporate Press Releases During Merger Negotiations. The Journal of Finance n/a-n/a. [CrossRef]

88. Han Soo Lee. 2013. Do National Economic and Political Conditions Affect Ideological Media Slant?. Political Communication 30, 395-418. [CrossRef]

89. Daniel Sutter. 2013. Broadcast meteorology and the supply of weather forecasts: an exploration. Journal of Economics and Finance 37, 463-477. [CrossRef]

90. Maria Alessandra Antonelli. 2013. Mass Media, Information and the Size of Bureaucracy. Procedia-Social and Behavioral Sciences 81, 562-569. [CrossRef]

91. Daniel F. Stone. 2013. Media and gridlock. Journal of Public Economics 101, 94-104. [CrossRef]

92. Kevin Arceneaux, Martin Johnson, John Cryderman. 2013. Communication, Persuasion, and the Conditioning Value of Selective Exposure: Like Minds May Unite and Divide but They Mostly Tune Out. Political Communication 30, 213-231. [CrossRef]

93. Deming Yang, Min Liu. 2013. Does the Media as a Watchdog Affect Auditors' Decisions?. China Accounting and Finance Review 15. . [CrossRef]

94. Gregory P. Casey, Ann L. Owen. 2013. Good News, Bad News, and Consumer Confidence. Social Science Quarterly 94:10.1111/ssqu.2013.94.issue-1, 292-315. [CrossRef]

95. Matthew S. Levendusky. 2013. Why Do Partisan Media Polarize Viewers?. American Journal of Political Science no-no. [CrossRef]

96. Marcel Garz. 2013. Unemployment expectations, excessive pessimism, and news coverage. Journal of Economic Psychology 34, 156-168. [CrossRef]

97. Armando J. Garcia Pires. 2013. Media Plurality and the Intensity of Readers' Political Preferences. Journal of Media Economics 26, 41-55. [CrossRef]

98. Hans Jarle Kind, Guttorm Schjelderup, Frank Stähler. 2013. Newspaper Differentiation and Investments in Journalism: The Role of Tax Policy. Economica 80:10.1111/ecca.2012.80.issue-317, 131-148. [CrossRef]

99. Fabrizio Germano, Martin Meier. 2013. Concentration and self-censorship in commercial media. Journal of Public Economics 97, 117-130. [CrossRef]

100. Dexin Tian, Chin-Chung Chao. 2012. Testing news trustworthiness in an online public sphere: a case study of The Economist 's news report covering the riots in Xinjiang, China. Chinese Journal of Communication 5, 455-474. [CrossRef]

101. Jean J. Gabszewicz, Joana Resende. 2012. Differentiated credence goods and price competition. Information Economics and Policy 24, 277-287. [CrossRef]

102. Gareth Campbell, John D. Turner, Clive B. Walker. 2012. The role of the media in a bubble. Explorations in Economic History 49, 461-481. [CrossRef]

103. Homero Gil de Zúñiga, Teresa Correa, Sebastian Valenzuela. 2012. Selective Exposure to Cable News and Immigration in the U.S.: The Relationship Between FOX News, CNN, and Attitudes Toward Mexican Immigrants. Journal of Broadcasting \& Electronic Media 56, 597-615. [CrossRef]

104. Daniel Sutter. 2012. Is the media liberal? An indirect test using news magazine circulation. Applied Economics 44, 3521-3532. [CrossRef]

105. Lona Fowdur, Vrinda Kadiyali, Jeffrey Prince. 2012. Racial bias in expert quality assessment: A study of newspaper movie reviews. Journal of Economic Bebavior \& Organization 84, 292-307. [CrossRef]

106. S. Iyengar, G. Sood, Y. Lelkes. 2012. Affect, Not Ideology: A Social Identity Perspective on Polarization. Public Opinion Quarterly 76, 405-431. [CrossRef]

107. WILLIAM P. BOTTOM, DEJUN TONY KONG. 2012. "THE CASUAL CRUELTY OF OUR PREJUDICES”: ON WALTER LIPPMANN'S THEORY OF STEREOTYPE AND ITS "OBLITERATION" IN PSYCHOLOGY AND SOCIAL SCIENCE. Journal of the History of the Bebavioral Sciences n/a-n/a. [CrossRef] 
108. Simon P. Anderson, John McLaren. 2012. MEDIA MERGERS AND MEDIA BIAS WITH RATIONAL CONSUMERS. Journal of the European Economic Association 10:10.1111/ jeea.2012.10.issue-4, 831-859. [CrossRef]

109. Maria Petrova. 2012. Mass Media and Special Interest Groups. Journal of Economic Behavior \& Organization . [CrossRef]

110. Thomas A. Lee. 2012. 'A helpless class of shareholder': newspapers and the City of Glasgow Bank failure. Accounting History Review 22, 143-159. [CrossRef]

111. Andrea Blasco, Francesco Sobbrio. 2012. Competition and commercial media bias. Telecommunications Policy 36, 434-447. [CrossRef]

112. Rafael Di Tella, Sebastian Galiani, Ernesto Schargrodsky. 2012. Reality versus propaganda in the formation of beliefs about privatization. Journal of Public Economics 96, 553-567. [CrossRef]

113. Shane Greenstein,, Feng Zhu. 2012. Is Wikipedia Biased?. American Economic Review 102:3, 343-348. [Abstract] [View PDF article] [PDF with links]

114. Ruben Durante, Brian Knight. 2012. PARTISAN CONTROL, MEDIA BIAS, AND VIEWER RESPONSES: EVIDENCE FROM BERLUSCONI'S ITALY. Journal of the European Economic Association 10, 451-481. [CrossRef]

115. PARTHA GANGOPADHYAY. 2012. ECONOMICS OF HATRED. International Journal of Development and Conflict 02, 1250005. [CrossRef]

116. UMIT G. GURUN, ALEXANDER W. BUTLER. 2012. Don't Believe the Hype: Local Media Slant, Local Advertising, and Firm Value. The Journal of Finance 67, 561-598. [CrossRef]

117. Casey Dougal, Joseph Engelberg, Diego García, Christopher A. Parsons. 2012. Journalists and the Stock Market. Review of Financial Studies 25, 639-679. [CrossRef]

118. Esther Gal-Or, Tansev Geylani, Tuba Pinar Yildirim. 2012. The Impact of Advertising on Media Bias. Journal of Marketing Research 49, 92-99. [CrossRef]

119. Kevin Arceneaux, Martin Johnson, Chad Murphy. 2012. Polarized Political Communication, Oppositional Media Hostility, and Selective Exposure. The Journal of Politics 74, 174-186. [CrossRef]

120. Matthew Gentzkow,, Jesse M. Shapiro,, Michael Sinkinson. 2011. The Effect of Newspaper Entry and Exit on Electoral Politics. American Economic Review 101:7, 2980-3018. [Abstract] [View PDF article] [PDF with links]

121. BRIAN J. FOGARTY. 2011. Modeling the Negotiation of Newsworthiness. Politics \& Policy 39:10.1111/ polp.2011.39.issue-6, 1053-1076. [CrossRef]

122. M. Gentzkow, J. M. Shapiro. 2011. Ideological Segregation Online and Offline. The Quarterly Journal of Economics . [CrossRef]

123. JOSHUA S. GANS, ANDREW LEIGH. 2011. How Partisan is the Press? Multiple Measures of Media Slant*. Economic Record no-no. [CrossRef]

124. Rafael Di Tella,, Ignacio Franceschelli. 2011. Government Advertising and Media Coverage of Corruption Scandals. American Economic Journal: Applied Economics 3:4, 119-151. [Abstract] [View PDF article] [PDF with links]

125. Valentino Larcinese, Riccardo Puglisi, James M. Snyder. 2011. Partisan bias in economic news: Evidence on the agenda-setting behavior of U.S. newspapers. Journal of Public Economics 95, 1178-1189. [CrossRef]

126. Patrick L. Warren. 2011. Independent Auditors, Bias, and Political Agency. Journal of Public Economics . [CrossRef]

127. Riccardo Puglisi, James M. Snyder. 2011. Newspaper Coverage of Political Scandals. The Journal of Politics 73, 931-950. [CrossRef]

128. J. F. M. Swinnen, P. Squicciarini, T. Vandemoortele. 2011. The food crisis, mass media and the political economy of policy analysis and communication. European Review of Agricultural Economics . [CrossRef] 
129. HELGE BERGER, MICHAEL EHRMANN, MARCEL FRATZSCHER. 2011. Monetary Policy in the Media. Journal of Money, Credit and Banking 43:10.1111/jmcb.2011.43.issue-4, 689-709. [CrossRef]

130. DAVID A. JONES, KATHLEEN FERRAIOLO, JENNIFER BYRNE. 2011. Selective Media Exposure and Partisan Differences about Sarah Palin's Candidacy. Politics \& Policy 39:10.1111/polp.2011.39.issue-2, 195-221. [CrossRef]

131. J. Duggan, C. Martinelli. 2011. A Spatial Theory of Media Slant and Voter Choice. The Review of Economic Studies 78, 640-666. [CrossRef]

132. Gene Birz, John R. Lott. 2011. The effect of macroeconomic news on stock returns: New evidence from newspaper coverage. Journal of Banking \& Finance . [CrossRef]

133. C.-F. Chiang, B. Knight. 2011. "Media Bias and Influence: Evidence from Newspaper Endorsements". The Review of Economic Studies . [CrossRef]

134. Daniel F. Stone. 2011. Ideological Media Bias. Journal of Economic Bebavior \& Organization . [CrossRef]

135. Nan Hu, Indranil Bose, Yunjun Gao, Ling Liu. 2011. Manipulation in digital word-of-mouth: A reality check for book reviews. Decision Support Systems 50, 627-635. [CrossRef]

136. Yi Xiang, David A. Soberman. 2011. Preview Provision Under Competition. Marketing Science 30, 149-169. [CrossRef]

137. Archishman Chakraborty,, Rick Harbaugh. 2010. Persuasion by Cheap Talk. American Economic Review 100:5, 2361-2382. [Abstract] [View PDF article] [PDF with links]

138. Magí Castelltort, Gabriela Mäder. 2010. Press media coverage effects on destinations - A Monetary Public Value (MPV) analysis. Tourism Management 31, 724-738. [CrossRef]

139. H. J. Kind, M. Koethenbuerger, G. Schjelderup. 2010. Tax responses in platform industries. Oxford Economic Papers 62, 764-783. [CrossRef]

140. J. F. M. Swinnen. 2010. The Political Economy of Agricultural and Food Policies: Recent Contributions, New Insights, and Areas for Further Research. Applied Economic Perspectives and Policy 32, 33-58. [CrossRef]

141. Todd D. Kendall. 2010. Strategic political commentary. Public Choice 142, 151-175. [CrossRef]

142. VINCENT BIGNON, ANTONIO MISCIO. 2010. Media bias in financial newspapers: evidence from early twentieth-century France. European Review of Economic History 14:03, 383. [CrossRef]

143. John T. Gasper. 2009. Reporting for sale: the market for news coverage. Public Choice 141, 493-508. [CrossRef]

144. Hanjoon Michael Jung. 2009. Information Manipulation Through the Media. Journal of Media Economics 22, 188-210. [CrossRef]

145. Steve Schifferes, Wainer Lusoli, Stephen Ward. 2009. What's the story...? Online news consumption in the 2005 UK election. Northern Lights 7, 51-71. [CrossRef]

146. Jimmy Chan, Wing Suen. 2009. Media as watchdogs: The role of news media in electoral competition. European Economic Review 53, 799-814. [CrossRef]

147. LILY FANG, JOEL PERESS. 2009. Media Coverage and the Cross-section of Stock Returns. The Journal of Finance 64:5, 2023-2052. [CrossRef]

148. ANDREW HEALY, NEIL MALHOTRA. 2009. Myopic Voters and Natural Disaster Policy. American Political Science Review 103, 387. [CrossRef]

149. Ascensión Andina-Díaz. 2009. Media competition and information disclosure. Social Choice and Welfare 33, 261-280. [CrossRef]

150. Utpal Bhattacharya, Neal Galpin, Rina Ray, Xiaoyun Yu. 2009. The Role of the Media in the Internet IPO Bubble. Journal of Financial and Quantitative Analysis 44, 657. [CrossRef]

151. Lee Becker, C. Ann Hollifield, Adam Jacobsson, Eva-Maria Jacobsson, Tudor Vlad. 2009. IS MORE ALWAYS BETTER?. Journalism Studies 10, 368-385. [CrossRef] 
152. Regina P. Branton, Johanna Dunaway. 2009. Slanted Newspaper Coverage of Immigration: The Importance of Economics and Geography. Policy Studies Journal 37:10.1111/psj.2009.37.issue-2, 257-273. [CrossRef]

153. Matthew Ellman, Fabrizio Germano. 2009. What do the Papers Sell? A Model of Advertising and Media Bias. The Economic Journal 119:10.1111/ecoj.2009.119.issue-537, 680-704. [CrossRef]

154. Alan S. Gerber,, Dean Karlan,, Daniel Bergan. 2009. Does the Media Matter? A Field Experiment Measuring the Effect of Newspapers on Voting Behavior and Political Opinions. American Economic Journal: Applied Economics 1:2, 35-52. [Abstract] [View PDF article] [PDF with links]

155. Shanto Iyengar, Kyu S Hahn. 2009. Red Media, Blue Media: Evidence of Ideological Selectivity in Media Use. Journal of Communication 59:10.1111/jcom.2009.59.issue-1, 19-39. [CrossRef]

156. W. Lance Bennett, Shanto Iyengar. 2008. A New Era of Minimal Effects? The Changing Foundations of Political Communication. Journal of Communication 58:10.1111/jcom.2008.58.issue-4, 707-731. [CrossRef]

157. Regina Branton, Johanna Dunaway. 2008. English- and Spanish-Language Media Coverage of Immigration: A Comparative Analysis *. Social Science Quarterly 89:10.1111/ssqu.2008.89.issue-4, 1006-1022. [CrossRef]

158. GÁBOR VIRÁG. 2008. Playing for Your Own Audience: Extremism in Two-Party Elections. Journal of Public Economic Theory 10:10.1111/jpet.2008.10.issue-5, 891-922. [CrossRef]

159. Jeremy Burke. 2008. Primetime Spin: Media Bias and Belief Confirming Information. Journal of Economics \& Management Strategy 17:10.1111/jems.2008.17.issue-3, 633-665. [CrossRef]

160. JIMMY CHAN, WING SUEN. 2008. A Spatial Theory of News Consumption and Electoral Competition. Review of Economic Studies 75, 699-728. [CrossRef]

161. Pierre L. Siklos, Martin T. Bohl. 2008. Policy words and policy deeds: the ECB and the euro. International Journal of Finance \& Economics 13:10.1002/ijfe.v13:3, 247-265. [CrossRef]

162. ALEXANDER DYCK, NATALYA VOLCHKOVA, LUIGI ZINGALES. 2008. The Corporate Governance Role of the Media: Evidence from Russia. The Journal of Finance 63:10.1111/ jofi.2008.63.issue-3, 1093-1135. [CrossRef]

163. Sendhil Mullainathan, Joshua Schwartzstein, Andrei Shleifer. 2008. Coarse Thinking and Persuasion*. Quarterly Journal of Economics 123, 577-619. [CrossRef]

164. Peter T. Leeson,. 2008. Media Freedom, Political Knowledge, and Participation. Journal of Economic Perspectives 22:2, 155-169. [Abstract] [View PDF article] [PDF with links]

165. Matthew Gentzkow,, Jesse M. Shapiro,. 2008. Competition and Truth in the Market for News. Journal of Economic Perspectives 22:2, 133-154. [Abstract] [View PDF article] [PDF with links]

166. Karel Jan Alsem, Steven Brakman, Lex Hoogduin, Gerard Kuper. 2008. The impact of newspapers on consumer confidence: does spin bias exist?. Applied Economics 40, 531-539. [CrossRef]

167. Nicola Gennaioli, Andrei Shleifer. 2008. Judicial Fact Discretion. The Journal of Legal Studies 37:10.1086/591649, 1-35. [CrossRef]

168. Yi Xiang, Miklos Sarvary. 2007. News Consumption and Media Bias. Marketing Science 26, 611-628. [CrossRef]

169. Bharat Anand, Rafael Di Tella, Alexander Galetovic. 2007. Information or Opinion? Media Bias as Product Differentiation. Journal of Economics \& Management Strategy 16:10.1111/jems.2007.16.issue-3, 635-682. [CrossRef]

170. William Chan, Li Hao, Wing Suen. 2007. A SIGNALING THEORY OF GRADE INFLATION. International Economic Review 48:10.1111/iere.2007.48.issue-3, 1065-1090. [CrossRef]

171. Stefano DellaVigna, Ethan Kaplan. 2007. The Fox News Effect: Media Bias and Voting*. Quarterly Journal of Economics 122:10.1162/qjec.2007.122.issue-3, 1187-1234. [CrossRef] 
172. Matthew E. Kahn. 2007. Environmental disasters as risk regulation catalysts? The role of Bhopal, Chernobyl, Exxon Valdez, Love Canal, and Three Mile Island in shaping U.S. environmental law. Journal of Risk and Uncertainty 35, 17-43. [CrossRef]

173. Ascensión Andina-Díaz. 2007. Reinforcement vs. change: The political influence of the media. Public Choice 131, 65-81. [CrossRef]

174. Germà Bel, Joan Calzada. 2007. Access Pricing to a Digital Broadcasting Platform. Journal of Media Economics 20, 29-53. [CrossRef]

175. Drew Fudenberg. 2006. Advancing Beyond Advances in Behavioral Economics. Journal of Economic Literature 44:3, 694-711. [Abstract] [View PDF article] [PDF with links]

176. Daniël Waagmeester, Frank Huysmans. 2006. 'Achter de schermen' bij 'Onderweg naar morgen': Overheidsdoelstellingen in een veranderende mediamarkt / Government policy goals in a changing media market. Tijdschrift voor Communicatiewetenschappen 34:10.1347/tijd.2006.34.issue-2, 155-165. [CrossRef]

177. Timothy Besley, Andrea Prat. 2006. Handcuffs for the Grabbing Hand? Media Capture and Government Accountability. American Economic Review 96:3, 720-736. [Abstract] [View PDF article] [PDF with links]

178. Xavier Gabaix, David Laibson. 2006. Shrouded Attributes, Consumer Myopia, and Information Suppression in Competitive Markets*. Quarterly Journal of Economics 121:10.1162/qjec.2006.121.issue-2, 505-540. [CrossRef]

179. Johan F. M. Swinnen, Nathalie Francken. 2006. Summits, Riots and Media Attention: The Political Economy of Information on Trade and Globalisation. The World Economy 29:10.1111/ twec.2006.29.issue-5, 637-654. [CrossRef]

180. Matthew Gentzkow, Jesse M. Shapiro. 2006. Media Bias and Reputation. Journal of Political Economy 114:10.1086/jpe.2006.114.issue-2, 280-316. [CrossRef]

181. Jonathan Reuter, Eric Zitzewitz. 2006. Do Ads Influence Editors? Advertising and Bias in the Financial Media*. Quarterly Journal of Economics 121:10.1162/qjec.2006.121.issue-1, 197-227. [CrossRef]

182. Kevin Wallsten, Dilyana TotevaHomophily and Online Politics 958-971. [CrossRef] 